\title{
Unification of Powers: When Effective Lawmakers Sponsor Presidential Proposals in Congress
}

\author{
Samuel Kernell, University of California, San Diego* \\ Roger Larocca, Oakland University \\ Craig Volden, University of Virginia \\ Alan E. Wiseman, Vanderbilt University
}

September 2021

\begin{abstract}
While scholars have long noted presidential powers over congressional lawmaking arising through persuasion, veto bargaining, and public appeals, we argue that an important tool is missing from this list. Specifically, presidents who are strategic in their choices of early coalition partners in Congress - such as effective sponsors of administration bills - significantly enhance their chance of legislative success. We use multiple sources to identify more than 1,400 executive branch proposals appearing as bills in Congress between 1989 and 2006. We examine which members of Congress sponsor these bills on the president's behalf, finding strong evidence of disproportionate sponsorship by effective champions, such as majority-party members, committee and subcommittee chairs, lawmakers with proven effectiveness in the previous Congress, party leaders, and senior lawmakers, all else equal. Analyzing the fate of these proposals, we find that much of the success of the president's agenda in Congress depends on these critical and strategic partnerships with effective congressional proponents.
\end{abstract}

\footnotetext{
* Prepared for presentation at the 2021 annual meetings of the American Political Science Association, Seattle. The authors thank Dan Grushkevich and Huchen Liu for valuable research assistance. NSF's grant (SES-0420124) to Kernell supported the collection and preparation of presidents' legislative initiatives. Volden and Wiseman thank the U.S. Democracy Program of the Hewlett Foundation and the Democracy Fund for their continued support for the Center for Effective Lawmaking (www.thelawmakers.org).
} 
Presidents come into office with major policy goals, ranging from Obama seeking to provide universal health care, to Trump's agenda on immigration and tax cuts, to Biden's plans on coronavirus relief, infrastructure, and climate change. Although presidents appear to rely increasingly on executive orders to advance their agendas unilaterally (Moe and Howell 1999), they do so mainly when frustrated by Congress' unwillingness to act. With public laws more durable and more financially secure than policies installed by executive orders, presidents would prefer congressional action and support. ${ }^{1}$

Whether presidents receive such support and achieve legislative success depends on many factors, both personal and situational. Their powers of persuasion (Neustadt 1960), their influence with the public (Kernell 2006), and their ability to marshal administrative expertise for their proposals (Larocca 2006) remain valuable resources in dealing with Congress.

Nevertheless, regardless of the skills the Oval Office politician, all their efforts may come to naught if Congress poses a hostile environment. Divided party control, ideological polarization, and even fissures within the president's own party in Congress pose obstacles that may be insurmountable. The fact that such unfavorable conditions frequently prevail in today's Washington has led presidents, and those who study them, to emphasize unilateral actions.

Over the past several decades, presidents have relied more heavily on veto threats, executive orders, and signing statements (which tilt the implementation of laws in the president's favor). Political science research has chronicled these rising domains of presidential leadership (e.g., Mayer 1999, Cooper 2005). Each of these techniques in some sense reflects a failure of

\footnotetext{
${ }^{1}$ Presidents may even use the threat of executive order as leverage to pry a bill out of Congress. President Trump, for example, threatened to issue an executive order in July 2020, to "bring fairness" to technology companies if Congress did not pass legislation to regulate "Big Tech" in a manner that was consistent with his priorities (https://www.businessinsider.com/trump-threatens-to-use-executive-orders-against-big-tech-2020-7, Accessed September 14, 2021).
} 
presidents to persuade Congress to adopt their preferred policies. Each represents a weak, fallback position. What all presidents prefer are new laws that accomplish their policy goals in a more enduring manner. Failing that, what they more frequently get are rescindable executive orders, gridlock, and untested assertions of authority. ${ }^{2}$ None of these matches the quality of Congress passing a new, White House-initiated law.

Despite increased scholarly attention devoted to these unilateral actions, presidents continue to send legislative initiatives to Congress. In this paper, we revisit such presidential efforts to better understand how presidents navigate the congressional landscape in hopes of achieving policy success. Specifically, we examine presidents' choices of congressional partners to introduce and advance their proposals. We argue that this first step in coalition-building - as viewed in their initial choice of bill sponsor - is crucial in setting a course for success or failure. Previous research (e.g., Volden and Wiseman 2014, 2018) demonstrates that bill sponsors vary significantly in their ability to move their legislative initiatives forward through the many stages of the lawmaking process and into law. Building on these findings, we seek to identify whether presidents exploit the House and Senate lawmaking talent pools when they seek legislative advocates for their bills. We then assess how the selection of a given sponsor contributes to (or detracts from) the likelihood that a bill ultimately becomes law.

To explore these possibilities, we have constructed a new dataset of 1,430 bills that presidents and other administration officials proposed between 1989 and 2006. We find that presidents are indeed strategic in their choices of bill sponsors, relying to a great extent on majority-party members, committee chairs, senior legislators, and those with a track record of effective lawmaking. We then show that these choices account for more than half of the boost in

\footnotetext{
${ }^{2}$ Thrower (2017) provides an in-depth analysis of the propensity for executive orders being revoked by subsequent administrations.
} 
the success of the president's legislative agenda, relative to bills that are put forward by others. Lawmaking is a team sport, one that successful presidents play well, overcoming some of the limitations of the American separation of powers system.

\section{Presidents Go to Congress}

Numerous systems of government around the world feature a tight connection between the executive and legislative branches. For example, in many countries a prime minister not only heads the executive branch but also offers legislative proposals as must-pass priorities in parliament. In contrast, the U.S. Constitution deals presidents a weak hand for extracting legislation from an independent and often opposed Congress. Essentially, presidents hold two interesting constitutional cards. The more potent one is the veto. It is an intentionally blunt instrument designed to allow presidents to block imprudent legislation. Had they been provided a line-item veto, presidents would have gained leverage for negotiating exchanges and winning policy battles. Yet, over the last several decades, presidents have leaned on vetoes (Cameron 2000) and especially veto threats (Sinclair 2014, Hassell and Kernell 2015, Guenther and Kernell 2021) to do more than block bad bills. The Framers, however, referred to the veto as "the Negative" for good reason. It limits presidents to responding to the policy agenda of others.

The second constitutional provision allows presidents more positive action but stops well short of allowing them to formally introduce legislation, or otherwise set the agenda in Congress. Article II, Section 3 provides that the president "shall from time to time give to the Congress Information of the State of the Union, and recommend to their Consideration such Measures as he shall judge necessary and expedient." Modern presidents certainly avail themselves of the opportunity in these addresses to tell the joint session of Congress (and a national television audience) the kinds of policy that they want. Since the early $20^{\text {th }}$ century, when presidents began 
personally delivering these speeches, they have delivered shopping lists of legislation to Congress. During the prewar years, FDR averaged 63 initiatives by Cohen's (2012) count. George W. Bush proposed 309 requests to his first Congress, by comparison, and the volume of his initiatives was not exceptional for his era. Whether Congress actually takes up these initiatives depends significantly on party control of Congress, as well as on presidents' efforts and determination. Presidents have, of course, expanded the State of the Union mandate from periodic to more-or-less continuous proposing and lobbying Congress for legislation. Even as divided government dominates Washington's politics, presidents have continued to press Congress with initiatives from their administration.

From time to time, scholars revisit the question of presidents' legislative leadership, and when they do, they find themselves at the outset asking a common question: "What is the president's program?" As noted above, presidents' opportunities to direct congressional attention are largely informal. ${ }^{3}$ The administration can request that an individual member of Congress introduce a bill on the president's behalf. Alternatively, congressional party and committee leaders may solicit recommendations for policy solutions from the White House and executive departments. Unlike proclamations and executive orders, the president's legislative initiatives are not neatly compiled and published in the Federal Register or anywhere else. As such, the president's influence on the legislative agenda may be very nearly invisible to observers beyond Capitol Hill.

Scholars who have sought to identify presidential initiatives in Congress have relied on various sources and alternative coding schemes. They often start with the incomplete and imprecise (but thoroughly codified) Public Papers of the President series, published by the

\footnotetext{
${ }^{3}$ In one chief exception, since the 1920 s, presidents have been statutorily required to send Congress an economic report with their budgetary requests for the next fiscal year.
} 
government printing office. Some data compilations (Malbin 2001) and research (Rudalevige 2002, Cohen 2012) stipulate that only public requests be included in presidents' legislative requests. ${ }^{4}$ Others supplement these lists with news coverage, or limit their analyses to only the most major initiatives. For example, Peterson (1990) and Edwards and Barrett (2000) examine landmark legislation, using Mayhew's (1991) criteria.

Given the variety of these data collection rules, we should expect to find presidents' success varying across studies as well as across Congresses. Peterson (1990) reports that 84 percent of important bills representing presidents' priorities receive legislative action, compared to 62 percent of minor bills. However, minor bills that do reach the active congressional agenda are more likely to get enacted (76 percent) than are major bills (58 percent). Rudalevige (2002) does not distinguish among bills with regard to legislative importance. His finding that 61 percent received "serious action" resides in the ballpark of Peterson's estimates. Adding further context, Edwards and Barrett (2000) report that the likelihood that the president's bill will be adopted nearly doubles under unified government. ${ }^{5}$

While virtually all of the studies in the extant literature draw their data from public communications, or at least initiatives sufficiently visible to receive press coverage, a wide range of initiatives are much harder to detect. They are neither catalogued nor easily subject to largesample empirical analysis. ${ }^{6}$ In order to better understand the importance of the relationship between the president and his key allies in Congress, we break with traditional approaches by

\footnotetext{
${ }^{4}$ Other important studies that rely heavily or exclusively on such public information are Light (1991) and Rudalevige (2002).

${ }^{5}$ For additional context, see the literature review by Cameron and Park (2008).

${ }^{6}$ An alternative approach looks at presidential positions on congressional votes, rather than at presidential initiatives themselves. During divided party control, presidents may become more preoccupied with preventing or moderating the opposition majority's ill-advised policies, leading some scholars to refer to the president's agenda as including efforts to preserve current policy. In embracing such a definition, some researchers (e.g., Bond and Fleisher 1991, Beckmann 2010) examine presidential influence in Congress through the study of roll call votes, including those on which the president urges defeat of a bill.
} 
examining only direct communications from the president to Congress, whether conveyed publicly or privately. Working with observations of direct contact between presidents and legislators, we examine the hand-off of proposals across from presidents (and their agents) to congressional bill sponsors. We seek to explore whether presidents are strategic in their choice of partners and how much it matters who carries the president's program into deliberations.

In doing so, we seek to tie together two distinct strands of American politics scholarship. One perspective speaks to how the American President has well-articulated policy goals, which he proactively seeks to secure and implement, as discussed above. A second perspective speaks to how individual members of Congress vary in their underlying lawmaking effectiveness, due both to their personal skills and to institutional positions that contribute to their success at advancing their sponsored bills. This latter perspective has a long tradition, dating back to the formative work of Matthews (1960) and Frantzich (1979). Using increasingly sophisticated approaches, more recent scholars (e.g., Anderson et al. 2003, Cox and Terry 2008) have established the importance of factors such as majority-party status, committee chair positions, and seniority of sponsors being linked to bill success in committee or on the floor of Congress. Volden and Wiseman (2014) offer a Legislative Effectiveness Score for each member of Congress, allowing scholars to further examine the patterns of whose proposals succeed under what conditions (e.g., Battaglini et al. 2020, Montgomery and Nyhan 2017).

Presidents may offer proposals for a variety of purposes, ranging from reelection seeking, to party branding, to actively addressing policy problems. To the extent that presidents wish to effect policy change through new legislation, partnering with effective lawmakers seems to be an important step forward. Yet, such a coupling between presidential proposals and congressional sponsors has not received systematic analysis by political scientists. We therefore offer two 
relatively straightforward hypotheses and subject them to empirical examination. First, we expect that presidents will select bill sponsors in the House and Senate who are best-positioned and equipped (with regards to their innate abilities and institutional positions) to move those bills furthest through the legislative process. Second, we expect that the combination of strategically chosen partners in Congress and the support and attention behind legislation coming from the president will heighten the success of these initiatives, more than either of these factors presidential proposals or effective sponsors - acting alone. We articulate these testable hypotheses more explicitly in the following statements:

Effective Sponsors for Presidential Bills Hypotheses: Presidents will rely disproportionately on effective lawmakers (including majority-party members, committee chairs, and senior legislators) to sponsor their bills in Congress.

Effective Sponsors Advance Presidential Initiatives Hypothesis: Reliance on effective lawmakers as sponsors significantly improves the advancement of presidential initiatives in Congress.

While these hypotheses focus on bill sponsors, our argument should be thought of in more general terms. Presidents make numerous strategic decisions in their early coalitionbuilding efforts in Congress. Bill sponsorship offers an important - yet incomplete - window into such strategic choices and their effects.

\section{Data}

In order to test our hypotheses, we need clear and meaningful indicators of which presidential initiatives were introduced as bills in the House and Senate; and we also need to account for the relative lawmaking effectiveness of the members of Congress who sponsor those bills. To identify whether a piece of legislation was, effectively, a "president's bill," we compile a list of executive-drafted bills introduced in the $101^{\text {st }}$ through $109^{\text {th }}$ Congresses (1989-2006) 
using three main (partially overlapping) sources: 1) Office of Management and Budget (OMB) logs of proposals submitted for legislative clearance, 2) Congressional Record entries of executive communications indicating that the president or an executive agency submitted a draft bill to Congress, and 3) Congressional Record mentions of bills introduced "by request." Before explicating the details about these different data sources, it is important to review how we define presidential bills.

As alluded to above, congressional rules specify that all bills considered in Congress must be introduced by a Representative or Senator, not by the president or any outside entity. In spite of these rules, many of the bills that are introduced in the modern Congress are actually written (in full or in part) by executive agencies, independent agencies, government corporations, state and local governments, and other public and private groups and individuals.

When bills are drafted by agencies, they can be transmitted to Congress, either by the president or by the agency. Many agency drafts that are transmitted to Congress are never introduced as bills in the House or Senate; these proposals have no congressional sponsor and are necessarily left out of our analysis. Hence, we classify "presidential bills" or "the president's bills" as those that are either transmitted to Congress by the president or authored by an executive agency and transmitted to Congress by that agency on behalf of the presidential administration. ${ }^{7}$ The bills transmitted directly by the president to Congress may be authored by executive agencies, but they can also be authored by White House staff, OMB staff, or a combination of these organizations and individuals (Rudalevige 2002). The characteristic that

\footnotetext{
${ }^{7}$ We do not classify bills that are authored and transmitted to Congress by independent, legislative, or judicial agencies as presidential bills. We also exclude the raft of budget rescission proposals that were put forward as individual bills in the $102^{\text {nd }}$ Congress on behalf of the president. President George H.W. Bush's strategy in this case was to have Rep. Harris Fawell (R-IL) and Sen. John McCain (R-AZ) put forward about 100 small rescission bills each, and then to package these together later in an attempt at budget cutting. Because these bills were not intended as proposals to be carried into law individually themselves, and because this strategy was not adopted anywhere else in our data, excluding these outliers from our analysis seemed to be appropriate.
} 
distinguishes all presidentially-transmitted bills from agency-transmitted bills is that they are sent to Congress with an accompanying letter from the president, rather than with a letter from an executive agency.

Most of the bills drafted by executive agencies are first submitted to OMB for legislative clearance before being transmitted to Congress. ${ }^{8}$ When these bills are approved by OMB, most are then transmitted directly to Congress by the authoring agency. Agencies usually indicate such approval by noting that the bill "is in accord with the program of the President" in the transmittal letter to Congress. ${ }^{9}$ Less frequently, bills can also be cleared "consistent with" the president's program or even with "no objection."10 We classify executive agency proposals cleared "in accord" or "consistent with" as presidential bills, even though they are transmitted to Congress directly by the agency. ${ }^{11}$

With respect to data sources, OMB logs give the most detailed information about executive-agency bills introduced in Congress. These logs indicate the agency authoring the bill, whether the bill was cleared and at what clearance level, and whether the bill was transmitted to Congress by the president, ${ }^{12}$ the agency, informally, or not at all. Most importantly, when an

\footnotetext{
${ }^{8}$ FDR created the legislative clearance process in 1934 with Budget Circular 336 in order to make sure that legislative proposals drafted by executive agencies were consistent with administration goals. Today, OMB clearance of both agency legislative proposals is governed by Circular A-19, last revised on September 20, 1979. ${ }^{9}$ OMB Circular A-19 states that "in accord" means that "the bill is of sufficient importance for the President to give it his personal and public support."

${ }^{10}$ Circular A-19 specifies that bills are cleared "consistent with" the president's program when the "relationship of a legislative proposal to the Administration's objectives is direct and the Administration's expressed support is desirable, but the item does not warrant personal identification with, or support by, the President."

${ }^{11}$ There is also a small number of bills cleared with "no objection," indicating an even lower level of administration support. All but three of these bills during our time period appear in the $101^{\text {st }}$ Congress. While these bills do not necessarily enjoy the support of the administration, we nevertheless characterize them as presidential bills when they are authored by executive agencies rather than independent agencies. Since we do not have OMB clearance data on all bills - either because some proposals circumvented OMB or because OMB failed to record them - we therefore cannot apply the OMB clearance level to determine whether these non-OMB bills are associated with the president. ${ }^{12}$ The Public Papers of the President is another valuable source of data about presidentially transmitted bills. Whenever an executive authored bill is transmitted to Congress by the president, the letter accompanying the bill (but not the draft bill itself) is printed in the Public Papers of the President. These proposals are, however, also listed in the OMB logs and Executive Communications ("Presidential Messages" in the Senate) section of the Congressional Record, and are thus redundant to our efforts.
} 
OMB-cleared bill is introduced in Congress, the OMB logs list the House or Senate bill number. This is the only data source that simultaneously identifies whether legislative proposals were authored by executive agencies and the actual H.R. or S. numbers of any bills that were introduced in Congress. However, the OMB logs are not complete; they do not include many executive-authored bills that appear in the other sources that we examine.

Our second main source - Executive Communications in the Congressional Recordform the most comprehensive catalog of executive proposals submitted to Congress. There can be 3,000 to 12,000 executive communications in a given Congress, but only a small fraction of these communications indicate the transmission of legislative proposals. Executive communications often (but not always) identify such details as the agency that has drafted the proposals, either the short title or the official title of a draft bill, the date of transmission to Congress, or the committee to which the bill was referred. The website congress.gov has digitized executive communications to the House and Senate for recent Congresses. However, unlike the OMB records, executive communications do not always indicate whether a draft bill was ever actually introduced in Congress, nor do they specify bill numbers or sponsors.

To determine whether each executive-communications proposal was introduced in Congress, it is insufficient to match the short title or official title of the bill with an identical bill introduced in Congress. Sometimes there are many matches for a given title; and even if there is only one match, there is no guarantee that it is the same bill as identified in the executive communication. Instead, we developed a systematic process that uses several congressional sources (sponsor introductory remarks, committee hearings, committee reports, floor debate, and committee legislative calendars) to match bills; we only assign a match when there is concrete documentary evidence from at least one of these sources to support executive authorship. 
The third method we use to uncover presidential bills in Congress also relies on the Congressional Record. The record offers one direct indicator that a bill was not drafted by the member of Congress sponsoring the bill - the "by request" label. However, neither congress.gov nor the Congressional Record indicates which individual or organization actually requested a "by request" bill. Moreover, the "by request" designation is not used solely for federal agency bills. State and local governments and private organizations can also request that a member of Congress introduce a bill, which are also frequently designated with the "by request" label. Therefore, we only code "by request" bills as executive-authored bills when we can identify concrete evidence of that authorship, using the same criteria that we apply to executive communications.

In total, these three overlapping approaches identify 1,430 bills from presidential administrations introduced in Congress during our period of study. Although our approach produces the most thorough and comprehensive listing of executive branch proposals before Congress to date, this data gathering effort has its limitations - increasingly so in more recent Congresses. Table B1 in the Supplemental Appendix, for example, shows a decline in the number of presidential initiatives captured by all three of our sources over the Congresses we study. We do not believe that presidents are less interested in advancing their policy ideas in Congress than they were in the past, however.

That said, the means used to detect those initiatives may need to change for future scholarship in this area. For instance, presidents appear to be relying more heavily on the White House Office of Legislative Affairs rather than OMB to screen agency proposals for new legislation; there has been a rise in "detailing" of executive agency legislative specialists, embedded within congressional committees on specific reform proposals, as an alternative to 
presenting administrative proposals to Congress whole-cloth; and there is less frequent official documentation of "by request" introductions, identifiers that are helpful to external observers but remain optional for members to include. Moreover, presidents more recently have sent members of Congress "Goals and Principles" documents or outlines of their priorities and left to Congress the exact details of the bill drafting (Weinberg 2018). Whether such a legislative strategy is more likely to succeed when compared to executive branch drafting is an open question. Nevertheless, future scholars looking to update our data to more recent Congresses may benefit from diving into these modern practices more fully, using techniques like FOIA requests or adapting text analysis techniques to more completely capture references to the origins of bills based on member introductory remarks or committee hearings.

With this list of presidential proposals in hand, we next identify the bill sponsors and the fate of each proposal. Our focus on the bill sponsors may be best viewed both in general and specific terms. Sponsors themselves may be valuable in their individual efforts to advance bills. Additionally, details about the sponsors may serve as something of a proxy for the president's coalition-building strategy more generally. Is he open to working with the opposing party? Has he sought and gained the support of key committee and party leaders? Does he recognize who the key players in Congress on the issue at hand might be? The bill sponsors themselves offer an important - but admittedly partial - window through which to examine that early legislative strategy.

We gather sponsor and bill fate information from Volden and Wiseman $(2014,2018)$, who track each bill through five stages of the lawmaking process and characterize each proposal in terms of its substantive significance. They use this information to create a "Legislative Effectiveness Score" for each member of the House and Senate in each Congress, designed to 
capture the "proven ability to advance a member's agenda items through the legislative process and into law" (Volden and Wiseman 2014, 18). More specifically, drawing on publicly available data from congress.gov, Volden and Wiseman identify how many public bills (H.R. or S. bill) each member of Congress introduced (BILL), how many of those bills received any action in committee (AIC) and/or action beyond committee (ABC), passed their chambers of origin (PASS), and became law (LAW) across a two-year Congress. Every bill is coded for its relative significance as being either commemorative, substantive, or substantive and significant, based on bill titles and mentions by the Congressional Quarterly news service. These fifteen bill-level indicators are then combined in a weighted average to calculate a Legislative Effectiveness Score (LES) normalized to have an average value of " 1 " for each chamber for every Congress since the 1970s.

Hence, the LES serves as a parsimonious metric of how successful a Representative or Senator is at moving her bills through the legislative process, in comparison to all other members of Congress, accounting for the relative significance of each bill in her portfolio. Analyzing these scores, Volden and Wiseman report that majority-party members, committee chairs, and more senior lawmakers are more effective, among other considerations. As such, to test the Effective Sponsors for Presidential Bills Hypotheses, we explore whether presidents rely to a greater degree on such lawmakers to carry their water in Congress. Due to endogeneity considerations - those who sponsor the president's bills may appear more effective simply due to the heightened success of presidential initiatives - we do not include Legislative Effectiveness Scores directly into our analyses. Instead, we include Lagged Legislative Effectiveness Score, which captures the lawmaker's prior successes, perhaps making them an attractive target for presidents to approach. 


\section{Do Presidents Look to Effective Lawmakers to Sponsor their Bills?}

To assess the president's legislative agenda and the scope of his successes, we begin by engaging with a fundamental question: which Members of Congress are most likely to carry the president's water in the legislative arena? Is it the case, as we postulate in our Effective Sponsors for Presidential Bills Hypothesis, that the president reaches out to those potential bill sponsors who are in particular positions of institutional influence, as well as those with a track record as effective lawmakers?

As an initial test, we might simply look at whether presidents rely on members of the majority party or members of their own party to advance the presidential initiative. On the one hand, copartisans with the president are more likely to share his policy goals and to benefit from his party branding or electoral efforts. On the other hand, members of the majority party are in a much better position to advance their bills through the Congress, which relies heavily on partisanship in its organization, from agenda setting right through to lawmaking (e.g., Cox and McCubbins 2005).

In Figure 1, we plot the percentage of a president's bills that are sponsored by members of his party in the House and Senate, between 1989 and 2006. It appears, at first glance, that this percentage fluctuates significantly across time. Upon closer inspection, however, we see that the time series follows a very predictable trend: nearly all of the president's bills are sponsored by a member of his party whenever his party holds the majority in the chamber of origin. These are the times when the president faces no tradeoff between the benefits of sponsorship by a member of his own party or by a member of the majority party. The two are one and the same. For example, when the Democrats were the majority party in the House and Senate in the $103^{\text {rd }}$ 
Congress (1993-1994), we see that almost all of President Clinton's bills were sponsored by his copartisans in the Democratic Party. ${ }^{13}$

\section{Figure 1: Percent of President's Bills Sponsored by Members of President's Party}

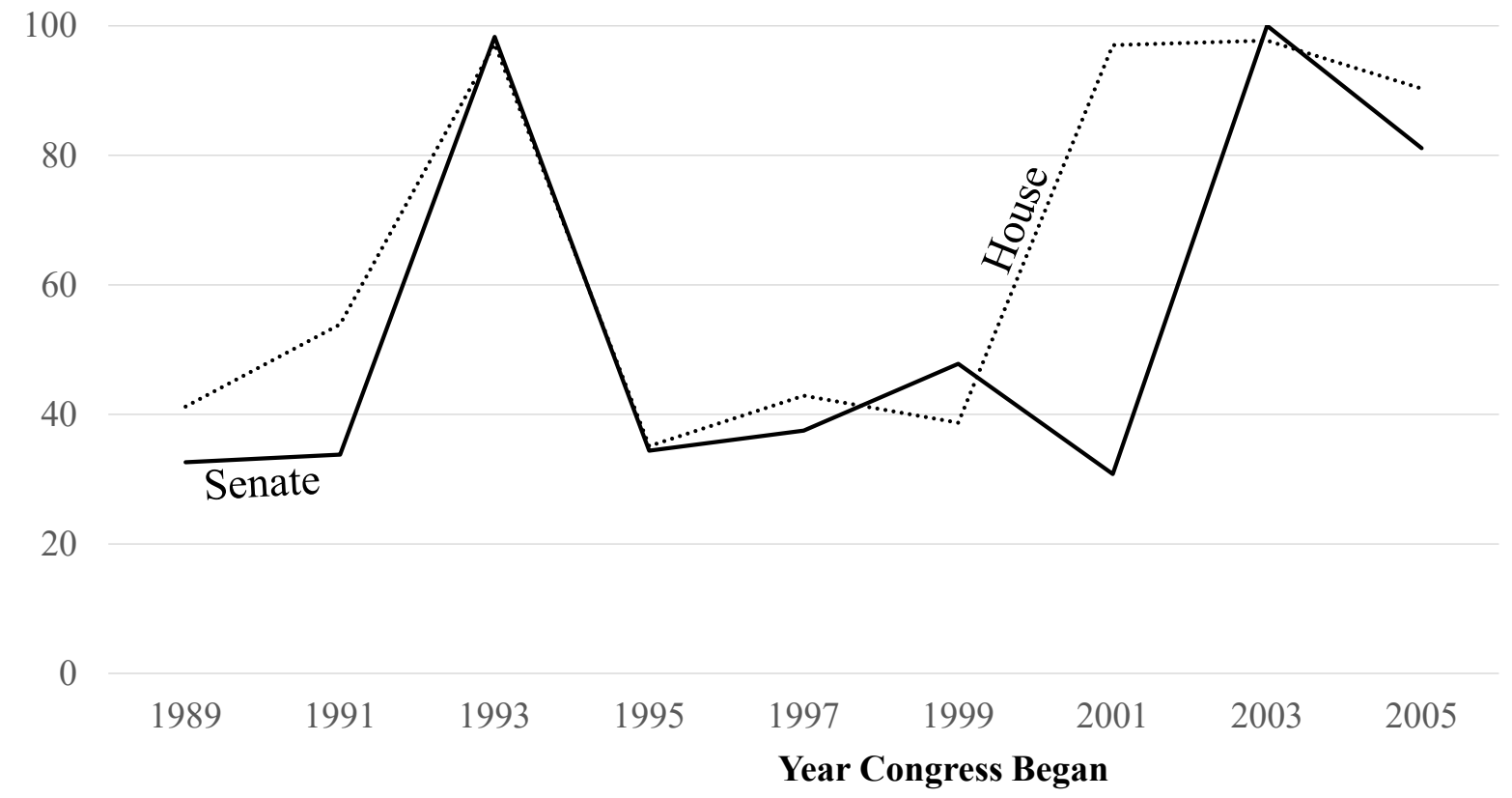

Note: The figure shows that about $90 \%$ of the president's bills in Congress are sponsored by members of his party when holding majority control of the chamber. This rate drops to around 40\% when the president's party is in the minority. These patterns are consistent with the Effective Sponsors for Presidential Bills Hypothesis, where the president looks beyond his own party to achieve success when in the minority.

When the president's party loses majority control of a chamber, however, the calculus becomes much more complicated. The president must balance affinity for his own party with the enhanced ability to move forward his agenda with majority-party support. Advancing the Clinton example, we see that when the Republicans took over the Congress in the "Republican Revolution" of the 1994 elections, less than $40 \%$ of the president's House- and Senate-initiated bills were sponsored by Democrats. It appears that, having seen his party lose majority control of the Congress, President Clinton was less concerned with having his bills advocated for by

\footnotetext{
${ }^{13}$ See Woodward (1994) for insights into the strategies used to advance the Clinton agenda early in his administration.
} 
members of his party, instead relying on members of the legislature in positions of greater lawmaking influence. A similar pattern obtains for each Congress and each chamber over the period of our study. When the president's party controls the chamber, about $90-100 \%$ of his agenda is advanced by copartisans. This falls to around $40 \%$ when the president's party is in the minority. A stark example is the $107^{\text {th }}$ Congress (2001-02) under President George W. Bush. Nearly all of his House bills were sponsored by majority-party Republicans, whereas Republicans put forward only a third of his initiatives in the Senate (which Democrats controlled once Sen. Jim Jeffords of Vermont switched parties early in 2001).

This seemingly strategic choice of working with members of the majority party suggests that presidents are acutely aware of the importance of building coalitional support for success from the earliest days of advancing a bill in Congress. Does such a strategic pattern of seeking out bill sponsors extend to finding specific members well-suited to carrying forward these initiatives, such as committee chairs, senior lawmakers, and those who have proven their effectiveness in the past? To answer this question, we create a dependent variable, Number of Presidential Bills Sponsored, which captures how many of the president's bills each member of the House and Senate sponsored within each Congress. We then conduct a number of negative binomial count model regressions, where the unit of analysis is the individual member of the House (Table 1) or the Senate (Table 2), and key dependent variables capture sponsor characteristics, including those central to our hypothesis and those shown to be associated with effective lawmaking in earlier studies (e.g., Volden and Wiseman 2014, 2018). All variables are described, along with summary statistics and data sources, in Appendix Table A1. 


\section{Table 1: Presidents Rely on Effective Lawmakers as House Bill Sponsors}

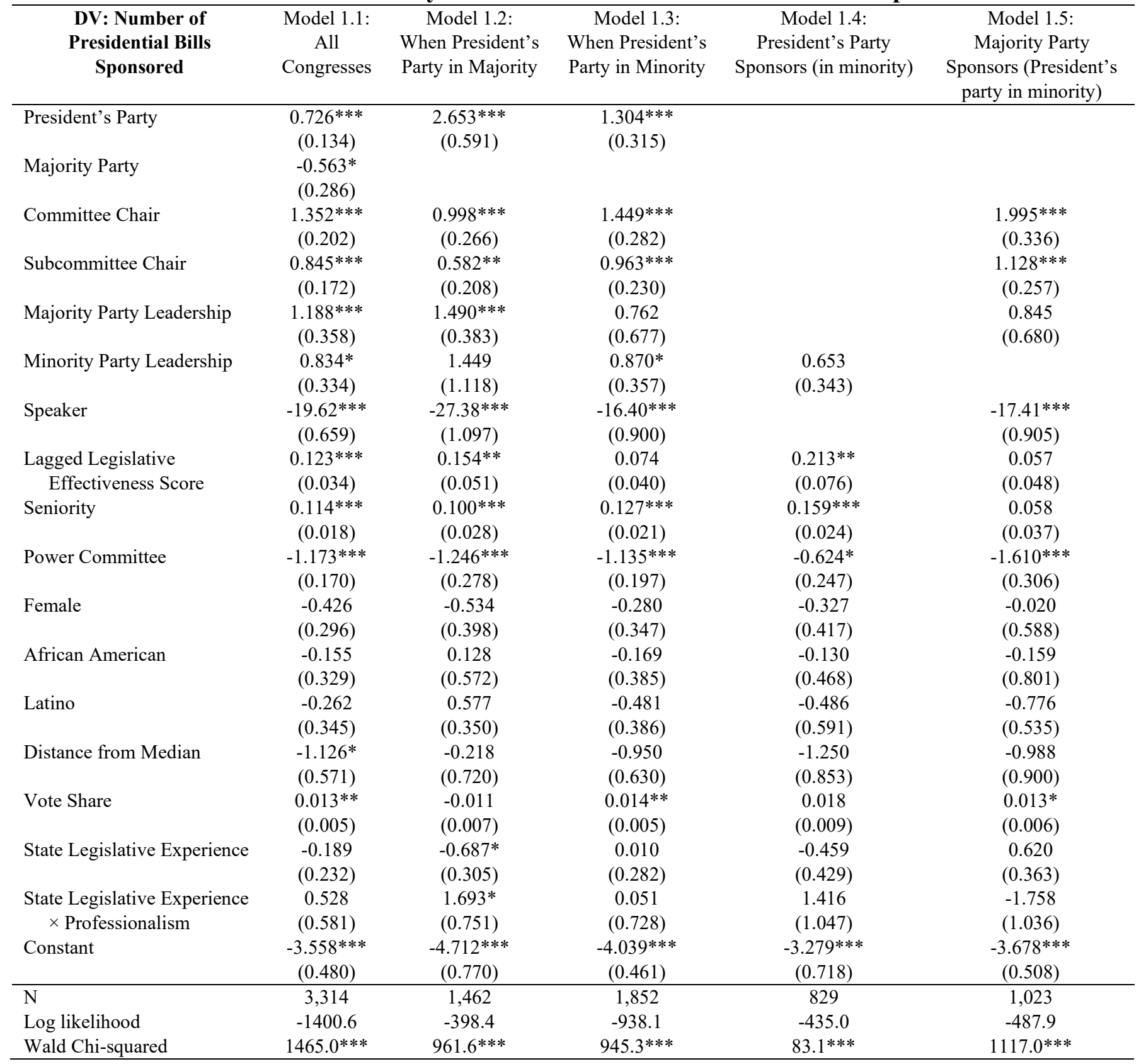

Notes: Results from negative binomial regressions, clustered by legislator, with robust standard errors in parentheses. Observations are members of the $101^{\text {st }}-109^{\text {th }}$ House (1989-2006). Model 1.1 contains all members in all Congresses. Model 1.2 contains all members during the $103^{\text {rd }}$, and $107^{\text {th }}-109^{\text {th }}$ Congresses, when the president's party controlled a majority in the House. Models $1.3-1.5$ contain the $101^{\text {st }}-102^{\text {nd }}$ and $104^{\text {th }}-106^{\text {th }}$ Congresses, when the president's party was the minority, examining all legislators (Model 1.3 ), only those in the president's party (Model 1.4), or only those in the majority party (Model 1.5), respectively. $* p<0.05, * * p<0.01, * * * p<0.001$ (two-tailed).

Consistent with the Effective Sponsors for Presidential Bills Hypothesis, the models show that committee and party leaders, senior legislators, and those with previous effectiveness sponsor more of the president's initiatives in the House. 
Model 1.1 includes all Representatives serving in Congresses between 1989-2006. In line with Figure 1, the model shows that presidents prefer to rely on their own party's members to put forward bill proposals. Most relevant for the Effective Sponsors for Presidential Bills Hypothesis, however, are the characteristics of effective lawmakers and the evidence that the president relies heavily on such lawmakers as sponsors of his initiatives. Most notably, presidents turn to a large degree to committee and subcommittee chairs to advance their legislation. This is a likely very astute strategy, given the immense influence of such individuals in the early stages of the lawmaking process - keeping the president's bills alive through committee agenda setting. Large and statistically significant coefficients on variables characterizing those in party leadership positions (with the exception of the Speaker of the House, who tends to introduce very few bills at all, including those from the president) also appear to indicate strategic choices on the president's part. Further in line with the Effective Sponsors for Presidential Bills Hypothesis, Model 1.1 shows a greater reliance on those who had high Legislative Effectiveness Scores in the previous Congress, as well as those with greater seniority. More subtly, presidents seem to rely less on members of "power committees" such as Rules, Ways and Means, or the Budget - who Volden and Wiseman (2014) show are less effective in their individual bills while they are focused on larger tax and budget packages as well as on broader institutional considerations.

As one example of strategic presidential partnerships along these lines, consider President Clinton's most prolific bill sponsoring partner in the $106^{\text {th }}$ Congress (1999-2000). Rather than working the most with a member of his own party, Clinton turned not once, not twice, but ten times to Rep. Bud Shuster (R-PA) to sponsor proposals from his administration. With fourteen terms of seniority, Shuster served as the powerful chair of the Transportation Committee. His 
effectiveness as a lawmaker had been repeatedly established, including by achieving an LES of 7.14 in the prior Congress, more than seven times the average score.

In Models 1.2 and 1.3, we examine the subsets of when the president's party was the House majority $\left(103^{\text {rd }}\right.$, and $107^{\text {th }}-109^{\text {th }}$ Congresses $)$ or minority $\left(101^{\text {st }}-102^{\text {nd }}\right.$, and $104^{\text {th }}-106^{\text {th }}$ Congresses), respectively. In comparing the magnitude of the coefficients on President's Party across these models, we see that presidential co-partisans are notably more likely to sponsor his bills when they hold the chamber majority than when they are in the minority. This is consistent with the findings of Figure 1 and with a reliance in particular on presidential copartisans when they are also well positioned to move his initiatives forward. These models also show a reliance on committee and subcommittee chairs regardless of whether they are from the president's own party, and a continued reliance on more senior members of the House. Model 1.2 shows the president relying on formerly effective lawmakers when his party is in the majority, but less so when in the minority (Model 1.3). We break this latter group down into further subsets of who the president relies on within his own party (Model 1.4) and in the majority party (Model 1.5) when cross-pressured due to the president's party being out of power in the House. Doing so shows a greater reliance on committee and subcommittee chairs within the majority party and on effective senior lawmakers in his own party, all else equal.

Table 2 presents the results from analogous analyses within the Senate. As further evidence in support of the Effective Sponsors for Presidential Bills Hypothesis, the same sets of patterns emerge across these models. Specifically, we see that the president relies on members of his own party much more frequently when they control the Senate (Model 2.2) than when they are the minority party (Model 2.3). Similar to our findings in the House, committee chairs and more senior senators introduce more of the president's bills, regardless of whether the president's 
party controls the Senate. Perhaps because nearly every majority-party Senator holds a subcommittee chair position, such institutional positions are less indicative of putting forth presidential proposals in the Senate than they were in the larger House.

We likewise see that those Senators who were shown to be more effective lawmakers in the past also introduce more of the president's bills, as indicated by the positive and statistically significant coefficient on Lagged Legislative Effectiveness Score in nearly all of the models. Put simply, presidents rely on those they believe can get the job done when seeking out partners as bill sponsors in Congress. For example, in the $102^{\text {nd }}$ Congress (1991-92), President Bush relied most heavily on two committee chairs across party lines in the Senate to carry forward his agenda. Sen. Claiborne Pell (D-RI) chaired the Foreign Relations Committee, while Sen. Alan Cranston (D-CA) chaired Veterans Affairs. Both were senior Senators who were known as effective lawmakers, and they both sponsored bills from the administration heavily in the $102^{\text {nd }}$ Senate (25 for Pell and 33 for Cranston). In contrast, Bush relied on Republicans much less frequently, with Sen. Bob Dole (R-KS) and Sen. Strom Thurmond (R-SC) being the most prolific at eight presidential sponsorships each in that Congress. ${ }^{14}$

Taken together, the results in Tables 1 and 2 offer significant support for the Effective Sponsors for Presidential Bills Hypothesis. Whether measured via their lagged Legislative Effectiveness Scores, their seniority, or based on their institutional positions in the chamber, such as being members of the majority party, or holding committee chairs, presidents disproportionately seek out those Representatives and Senators who have been (and can continue to be) more effective lawmakers to sponsor their bills in Congress.

\footnotetext{
${ }^{14}$ For more on the strategic decisions made to advance policy goals within the George H.W. Bush administration, see the insights from oral histories in Nelson and Perry (2014).
} 
Table 2: Presidents Rely on Effective Lawmakers as Senate Bill Sponsors

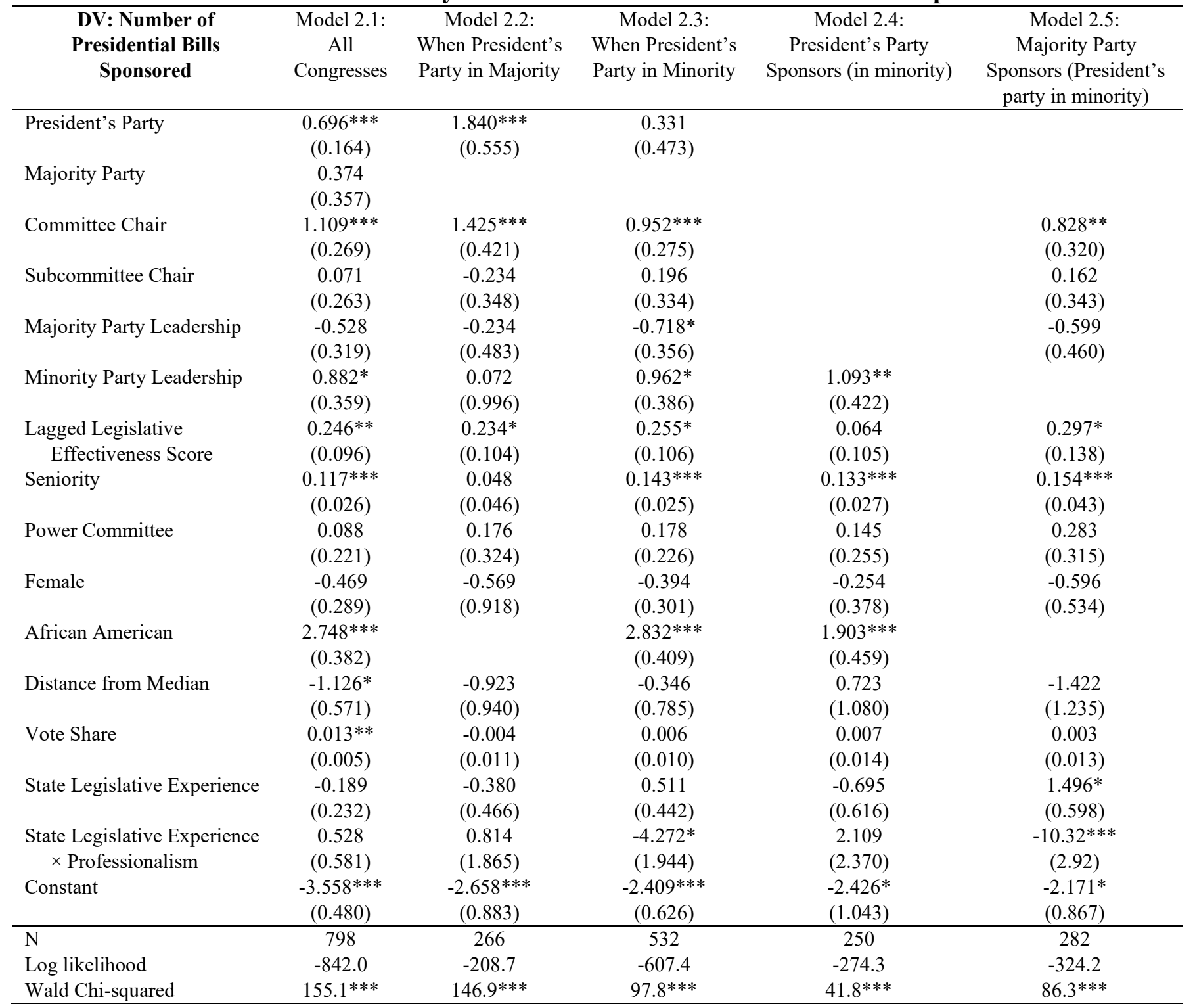

Notes: Results from negative binomial regressions, clustered by Senator, with robust standard errors in parentheses. Observations are members of the $101^{\text {st }}-109^{\text {th }}$ U.S. Senate (1989-2006). Model 2.1 contains all members in all Congresses. Model 2.2 contains all members during the $103^{\text {rd }}, 108^{\text {th }}$, and $109^{\text {th }}$ Congresses, when the president's party controlled a majority in the Senate. Models $2.3-2.5$ contain the $101^{\text {st }}-102^{\text {nd }}$ and $104^{\text {th }}-107^{\text {th }}$ Congresses, when the president's party was the minority, examining all Senators (Model 2.3), only those in the president's party (Model 2.4), or only those in the majority party (Model 2.5), respectively. $* p<0.05, * * p<0.01, * * * p<0.001$ (two-tailed).

Consistent with the Effective Sponsors for Presidential Bills Hypothesis, the models show that committee and party leaders, senior Senators, and those with previous effectiveness sponsor more of the president's initiatives in the Senate. 


\section{Does the Choice of Bill Sponsor Translate into Legislative Success?}

Having identified the characteristics of Representatives and Senators who are most likely to sponsor the president's bills, the next natural question to engage with is: what happens to those bills? What are the chances that the president's legislative initiatives advance through the different hurdles in the lawmaking process to ultimately become law? Relatedly, are the president's bills more or less likely to advance further through the legislative process than measures that do not originate the president? And can we assess the extent to which the president's selection of specific advocates for his bills contributes - in a positive way - to the chances that they become law, compared to the fate they may have experienced without such strategic partnerships?

As a baseline from which to engage with these questions, in Figure 2, we illustrate the percent of presidential bills that become law over our time period, with several patterns emerging. First, the percentage of the president's bills that ultimately become law in both chambers has fluctuated over time, ranging from a low point of approximately $5 \%$ for Senate initiated bills during the Clinton Presidency in 1993-94 (despite unified Democratic government), to a high water mark of approximately $35 \%$ of House initiated bills during the George W. Bush Presidency in 2003-04 (under unified Republican government). ${ }^{15}$ That said, second, there appears to be a positive trend across time, such that for both chambers, a greater percentage of president's bills have become law in more recent Congresses. ${ }^{16}$ Third, for the entire duration of the our sample, presidential bills that begin in the House are notably more

\footnotetext{
${ }^{15}$ The low water mark taking place in the $103^{\text {rd }}$ Senate comports with journalistic accounts (e.g., Woodard 1994, 286-288) that point to the difficulties President Clinton experienced in navigating the legislative process with Democratic Senators in the first two years of his presidency.

${ }^{16}$ We hesitate to place too much emphasis on such trends, however, given the decline in the number of bills that our approach detects in these later Congresses (see Appendix Table B1).
} 
likely to become law than are those that begin in the Senate. In some Congresses, such as the $106^{\text {th }}$ Congress (2001-02), the difference in success rates between the House (i.e., greater than $30 \%$ ) and the Senate (i.e., less than 10\%) are especially stark. Fourth, regardless of whether bills begin in the Senate or House, the percentage of the president's bills that ultimately become law is substantially greater than the percentage of all bills that are introduced into Congress that become law (approximately $4-5 \%$ during this period of time).

\section{Figure 2: Percent of President's Bills Becoming Law}

40

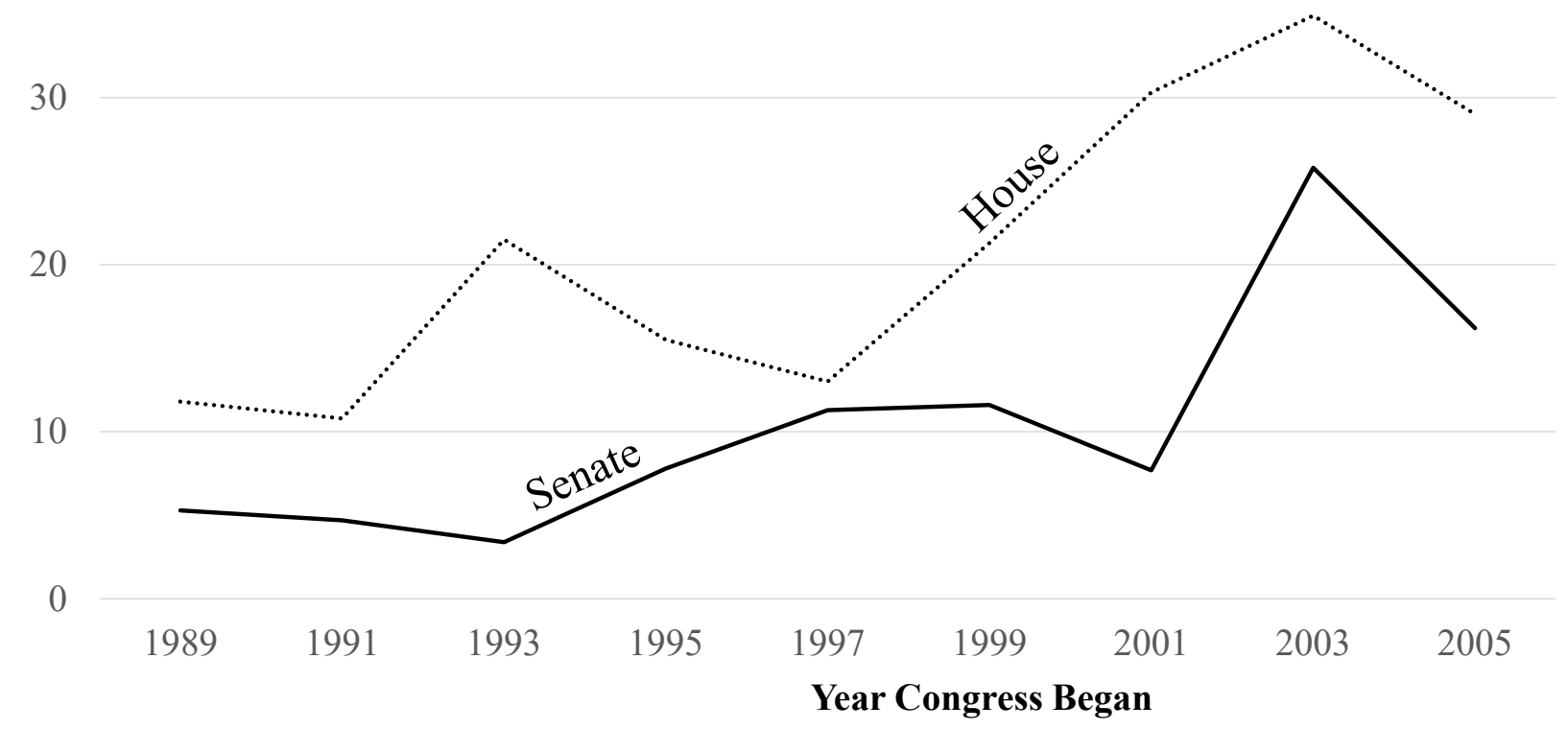

Notes: The figure shows the percent of the president's bills in Congress that become law, based on the Congress and chamber. On average, presidential proposals significantly outperform the approximately $4-5 \%$ success rate of other proposals in Congress, with some variance depending on the chamber of introduction and considerations such as unified or divided government.

On its face, the findings in Figure 2 suggest that the president's initiatives in Congress are more likely to become law than other (i.e., non-presidential) bills. However, it is difficult to discern from such aggregate patterns alone whether this higher rate of success may be due to the fact that the bill is a presidential priority, or that the president found effective advocates for his 
initiatives, or both. To try to unpack these findings, we turn to the level of analysis of individual bills - both those originating with the administration and those coming from non-presidential sources. We then conduct a series of logit regressions looking at each subsequent major stage of the lawmaking process after the bill has been introduced. For example, in Table 3 we include as our dependent variable an indicator for whether the bill received any "Action in Committee," such as a hearing, markup, or subcommittee vote. As independent variables, we include an indicator for whether the bill is a President's Bill, as well as all of the variables from Tables 1 and 2 that capture bill sponsor characteristics. ${ }^{17}$ Models 3.1 and 3.2 focus on bills that were introduced into the House, where Model 3.1 analyzes all public bills that were introduced, and Model 3.2 is limited only to the subset of presidential bills. Models 3.3 and 3.4 present analogous findings from the Senate.

For both House and Senate bills, we see in Models 3.1 and 3.3 that the President's Bills are much more likely to be included on the committee's active agenda than are other bills. Moreover, the sorts of lawmakers that the administration sought out as bill sponsors are shown to indeed be very effective in gaining attention for their bills. Specifically, bills that are sponsored by Representatives and Senators in particular positions of institutional influence are more likely to receive some sort of action in committee. For both chambers, bills that are sponsored by committee chairs and other members of the majority party are more likely to receive action on the committee's agenda. Moreover, for House bills, there is a positive relationship between receiving action in committee and being sponsored by subcommittee chairs and by majorityparty leaders.

\footnotetext{
${ }^{17}$ Bill-level variable descriptions, along with summary statistics and data sources, are given in Appendix Table A2. Models including or excluding such additional factors as unified or divided government, or Congress fixed effects, result in similar levels of support for the Effective Sponsors Advance Presidential Initiatives Hypothesis as those reported here.
} 


\section{Table 3: Effective Lawmakers Move Presidents' Policies onto Agenda}

\begin{tabular}{|c|c|c|c|c|}
\hline $\begin{array}{c}\text { DV: Bill Received "Action } \\
\text { in Committee" }\end{array}$ & $\begin{array}{l}\text { Model 3.1: } \\
\text { House } \\
\text { All Bills }\end{array}$ & $\begin{array}{c}\text { Model 3.2: } \\
\text { House } \\
\text { President's Bills }\end{array}$ & $\begin{array}{l}\text { Model 3.3: } \\
\text { Senate } \\
\text { All Bills }\end{array}$ & $\begin{array}{c}\text { Model 3.4: } \\
\text { Senate } \\
\text { President's Bills }\end{array}$ \\
\hline President's Bill & $\begin{array}{l}1.218^{* * *} \\
(0.132)\end{array}$ & & $\begin{array}{c}0.787 * * * \\
(0.183)\end{array}$ & \\
\hline Majority Party & $\begin{array}{c}0.638 * * * \\
(0.120)\end{array}$ & $\begin{array}{c}1.976 * * * \\
(0.527)\end{array}$ & $\begin{array}{c}0.524 * * * \\
(0.141)\end{array}$ & $\begin{array}{l}2.274 * * * \\
(0.412)\end{array}$ \\
\hline Committee Chair & $\begin{array}{c}0.550 * * * \\
(0.112)\end{array}$ & $\begin{array}{l}0.908^{*} \\
(0.403)\end{array}$ & $\begin{array}{l}0.316^{* * *} \\
(0.097)\end{array}$ & $\begin{array}{r}-0.286 \\
(0.369)\end{array}$ \\
\hline Subcommittee Chair & $\begin{array}{c}0.375 * * * \\
(0.067)\end{array}$ & $\begin{array}{c}0.334 \\
(0.358)\end{array}$ & $\begin{array}{l}-0.074 \\
(0.096)\end{array}$ & $\begin{array}{l}-0.895 * * \\
(0.302)\end{array}$ \\
\hline Majority Party Leadership & $\begin{array}{c}0.541 * * * \\
(0.128)\end{array}$ & $\begin{array}{l}2.818^{*} \\
(1.148)\end{array}$ & $\begin{array}{l}-0.139 \\
(0.127)\end{array}$ & $\begin{array}{c}0.123 \\
(0.395)\end{array}$ \\
\hline Minority Party Leadership & $\begin{array}{l}-0.353 \\
(0.201)\end{array}$ & $\begin{array}{l}-0.210 \\
(0.566)\end{array}$ & $\begin{array}{l}-0.126 \\
(0.169)\end{array}$ & $\begin{array}{l}-0.827 \\
(0.493)\end{array}$ \\
\hline Speaker & $\begin{array}{c}0.296 \\
(0.586)\end{array}$ & & & \\
\hline $\begin{array}{l}\text { Lagged Legislative } \\
\text { Effectiveness Score }\end{array}$ & $\begin{array}{c}0.069 * * * \\
(0.015)\end{array}$ & $\begin{array}{l}-0.062 \\
(0.038)\end{array}$ & $\begin{array}{c}0.118^{* * * *} \\
(0.025)\end{array}$ & $\begin{array}{c}0.022 \\
(0.086)\end{array}$ \\
\hline Seniority & $\begin{array}{c}0.009 \\
(0.009)\end{array}$ & $\begin{array}{l}-0.001 \\
(0.029)\end{array}$ & $\begin{array}{l}-0.008 \\
(0.010)\end{array}$ & $\begin{array}{l}-0.043 \\
(0.039)\end{array}$ \\
\hline Power Committee & $\begin{array}{c}-0.543 * * * \\
(0.078)\end{array}$ & $\begin{array}{l}-0.260 \\
(0.297)\end{array}$ & $\begin{array}{l}-0.196^{*} \\
(0.080)\end{array}$ & $\begin{array}{l}-0.171 \\
(0.267)\end{array}$ \\
\hline Female & $\begin{array}{c}-0.445^{* * *} \\
(0.088)\end{array}$ & $\begin{array}{c}0.311 \\
(0.568)\end{array}$ & $\begin{array}{l}-0.333 \\
(0.226)\end{array}$ & $\begin{array}{l}1.150^{*} \\
(0.470)\end{array}$ \\
\hline African American & $\begin{array}{c}0.002 \\
(0.112)\end{array}$ & $\begin{array}{l}-0.745 \\
(0.398)\end{array}$ & $\begin{array}{l}-0.172 \\
(0.226)\end{array}$ & \\
\hline Latino & $\begin{array}{c}0.180 \\
(0.142)\end{array}$ & $\begin{array}{l}-0.543 \\
(0.624)\end{array}$ & & \\
\hline Distance from Median & $\begin{array}{l}-0.399 \\
(0.238)\end{array}$ & $\begin{array}{l}1.579 * \\
(0.776)\end{array}$ & $\begin{array}{l}-0.426 \\
(0.296)\end{array}$ & $\begin{array}{c}0.287 \\
(1.154)\end{array}$ \\
\hline Vote Share & $\begin{array}{l}-0.002 \\
(0.002)\end{array}$ & $\begin{array}{c}-0.023 * * \\
(0.008)\end{array}$ & $\begin{array}{c}0.014 * * * \\
(0.004)\end{array}$ & $\begin{array}{c}0.008 \\
(0.013)\end{array}$ \\
\hline State Legislative Experience & $\begin{array}{c}0.084 \\
(0.117)\end{array}$ & $\begin{array}{l}-0.077 \\
(0.465)\end{array}$ & $\begin{array}{c}0.067 \\
(0.161)\end{array}$ & $\begin{array}{c}0.545 \\
(0.665)\end{array}$ \\
\hline $\begin{array}{l}\text { State Legislative Experience } \\
\times \text { Professionalism }\end{array}$ & $\begin{array}{l}0.0003 \\
(0.314)\end{array}$ & $\begin{array}{c}1.425 \\
(1.250)\end{array}$ & $\begin{array}{c}0.046 \\
(0.672)\end{array}$ & $\begin{array}{l}-1.164 \\
(2.700)\end{array}$ \\
\hline Constant & $\begin{array}{c}-2.101 * * * \\
(0.190)\end{array}$ & $\begin{array}{l}-0.760 \\
(0.756)\end{array}$ & $\begin{array}{c}-2.223 * * * \\
(0.289)\end{array}$ & $\begin{array}{l}-1.329 \\
(1.084)\end{array}$ \\
\hline $\mathrm{N}$ & 44,619 & 663 & 25,434 & 719 \\
\hline Log likelihood & $-17,940.8$ & -376.6 & $-13,383.0$ & -450.7 \\
\hline Wald Chi-squared & $730.6^{* * *}$ & $104.6 * * *$ & $294.5^{* * *}$ & $82.8^{* * *}$ \\
\hline
\end{tabular}

Notes: Results from logit regressions, clustered by legislator, with robust standard errors in parentheses. Observations are bills sponsored the $101^{\text {st }}-109^{\text {th }}$ Congresses (1989-2006). The dependent variable takes a value of one for bills receiving action in committee, such as a hearing, mark-up, or vote. Models 3.1 and 3.2 focus on House bills (H.R.), whereas Models 3.3 and 3.4 focus on Senate bills (S.). Models 3.2 and 3.4 only include bills coming from the administration.

$* p<0.05, * * p<0.01, * * * p<0.001$ (two-tailed).

Consistent with the Effective Sponsors Advance Presidential Initiatives Hypothesis, the models show that presidential initiatives find their way onto the agenda more frequently, especially when sponsored by those who were shown to sponsor such bills at a greater rate in the previous analyses. 
We also see that bills that have been sponsored by Representatives and Senators who were highly effective lawmakers in previous Congresses (Lagged Legislative Effectiveness Score) are more likely to receive action in committee. Put simply, the same characteristics that presidents relied upon in selecting their bills' sponsors turn out to be closely related to bills advancing within committees.

Among these strategically chosen partners, is there a further differentiation with respect to which of them achieved the greatest success when called upon to sponsor presidential bills? Turning to Models 3.2 and 3.4, which focus solely on the president's bills, we find somewhat mixed results. First, we see that several of the core findings from analysis of the full sample translate to this smaller sample: presidential bills that are sponsored by members of the majority party are more likely to receive action in committee, and committee chair sponsorship likewise contributes to more action in committee in the House. However, for both the House and the Senate, we see that many of the factors that determine success in committee for bills in general do not have an outsized role for presidential initiatives. For instance, there is essentially no relationship between whether a sponsor was a highly effective lawmaker in the previous Congress and whether the president's bill that she sponsors in the current Congress receives any action in committee.

On its face, this latter result might suggest that a sponsor's lawmaking effectiveness has little impact on whether the bills that she sponsors on behalf of the president advance through the initial stages of the legislative process. We believe that such a conclusion is premature, however, given that our previous analyses (in Tables 1 and 2) demonstrate that the president unambiguously relies on effective lawmakers (as indicated by their lagged effectiveness scores, for example) to carry water for him. For example, the average lagged LES for Representatives 
who sponsor the president's bills is 2.71 , indicating that on average they are nearly three times as effective as the average member of the House. Were the president to instead have selected bill sponsors at random, we believe that low-performers on their own bills would have been relatively ineffective in advancing the president's bills as well. Models 3.2 and 3.4 instead suggest that, among this elite group of high performers there is little further differentiation in which sponsors of the president's bills achieve greater or less success. ${ }^{18}$ Below, we entertain more fully the counterfactual of the president's success rates were he to have selected bill sponsors at random instead of using the strategic process uncovered in Tables 1 and 2.

Moving beyond the "action in committee" stage of lawmaking to further steps toward the president's bills becoming law, we replicate the analyses from Table 3 looking at "action beyond committee" for bills that reach the floor of their home chambers, "passage" for those that pass their home chambers, and "becoming law" for those actually enacted. We show the models from the last of these analyses in Table 4, while placing the intermediate stage models in the Appendix in Tables A3 and A4.

The results of these analyses are quite similar to our findings in Table 3 , in that we see that, for both House and Senate bills (in Models 4.1 and 4.3), bills that are sponsored by committee chairs and other members of the majority party are more likely to become law; and for House bills, we also see that there is a positive relationship between being sponsored by subcommittee chairs or by majority party leaders and becoming law. Moreover, once again bills sponsored by previously effective lawmakers in both the House and Senate are more likely to become law.

\footnotetext{
${ }^{18}$ This may be similar to the form of selection bias that results in height no longer being a good predictor of success among NBA players or math GRE scores no longer being a good predictor of success among those in math $\mathrm{PhD}$ programs (https://statmodeling.stat.columbia.edu/2020/09/26/does-this-fallacy-have-a-name/).
} 
Table 4: Effective Lawmakers Advance Presidents' Policies into Law

\begin{tabular}{|c|c|c|c|c|}
\hline DV: Bill Became Law & $\begin{array}{l}\text { Model 4.1: } \\
\text { House } \\
\text { All Bills } \\
\end{array}$ & $\begin{array}{c}\text { Model 4.2: } \\
\text { House } \\
\text { President's Bills } \\
\end{array}$ & $\begin{array}{l}\text { Model 4.3: } \\
\text { Senate } \\
\text { All Bills }\end{array}$ & $\begin{array}{c}\text { Model 4.4: } \\
\text { Senate } \\
\text { President's Bills } \\
\end{array}$ \\
\hline President's Bill & $\begin{array}{l}1.019 * * * \\
(0.140)\end{array}$ & & $\begin{array}{c}0.466 \\
(0.248)\end{array}$ & \\
\hline Majority Party & $\begin{array}{c}0.626^{* * *} \\
(0.137)\end{array}$ & $\begin{array}{c}3.164 * * * \\
(0.777)\end{array}$ & $\begin{array}{c}0.707 * * * \\
(0.218)\end{array}$ & $\begin{array}{r}2.048^{*} \\
(0.889)\end{array}$ \\
\hline Committee Chair & $\begin{array}{c}0.644 * * * \\
(0.113)\end{array}$ & $\begin{array}{c}0.637 \\
(0.389)\end{array}$ & $\begin{array}{c}0.391 * * \\
(0.129)\end{array}$ & $\begin{array}{c}0.130 \\
(0.472)\end{array}$ \\
\hline Subcommittee Chair & $\begin{array}{l}0.203^{*} \\
(0.081)\end{array}$ & $\begin{array}{l}-0.151 \\
(0.348)\end{array}$ & $\begin{array}{c}0.036 \\
(0.131)\end{array}$ & $\begin{array}{r}-0.513 \\
(0.523)\end{array}$ \\
\hline Majority Party Leadership & $\begin{array}{c}0.683 * * * \\
(0.151)\end{array}$ & $\begin{array}{l}1.633^{*} \\
(0.650)\end{array}$ & $\begin{array}{c}0.156 \\
(0.188)\end{array}$ & $\begin{array}{r}-1.690 \\
(1.155)\end{array}$ \\
\hline Minority Party Leadership & $\begin{array}{l}-0.178 \\
(0.276)\end{array}$ & & $\begin{array}{l}-0.030 \\
(0.290)\end{array}$ & \\
\hline Speaker & $\begin{array}{l}1.779^{*} \\
(0.710)\end{array}$ & & & \\
\hline $\begin{array}{l}\text { Lagged Legislative } \\
\text { Effectiveness Score }\end{array}$ & $\begin{array}{c}0.047 * * * \\
(0.013)\end{array}$ & $\begin{array}{l}-0.030 \\
(0.048)\end{array}$ & $\begin{array}{c}0.113 * * * \\
(0.035)\end{array}$ & $\begin{array}{l}-0.076 \\
(0.132)\end{array}$ \\
\hline Seniority & $\begin{array}{c}0.013 \\
(0.012)\end{array}$ & $\begin{array}{l}-0.016 \\
(0.036)\end{array}$ & $\begin{array}{l}-0.021 \\
(0.016)\end{array}$ & $\begin{array}{l}-0.118^{*} \\
(0.047)\end{array}$ \\
\hline Power Committee & $\begin{array}{c}0.008 \\
(0.100)\end{array}$ & $\begin{array}{l}0.636^{*} \\
(0.310)\end{array}$ & $\begin{array}{l}-0.211 \\
(0.115)\end{array}$ & $\begin{array}{l}-0.319 \\
(0.467)\end{array}$ \\
\hline Female & $\begin{array}{c}-0.360 * * \\
(0.132)\end{array}$ & $\begin{array}{l}-0.794 \\
(1.009)\end{array}$ & $\begin{array}{l}-0.447 \\
(0.250)\end{array}$ & $\begin{array}{l}0.505 \\
(0.606)\end{array}$ \\
\hline African American & $\begin{array}{l}0.375^{*} \\
(0.172)\end{array}$ & $\begin{array}{l}-1.410^{*} \\
(0.707)\end{array}$ & & \\
\hline Latino & $\begin{array}{c}0.465^{* *} \\
(0.166)\end{array}$ & $\begin{array}{l}-0.513 \\
(0.426)\end{array}$ & & \\
\hline Distance from Median & $\begin{array}{l}-0.466 \\
(0.273)\end{array}$ & $\begin{array}{l}2.205 * \\
(1.075)\end{array}$ & $\begin{array}{c}0.576 \\
(0.418)\end{array}$ & $\begin{array}{c}0.593 \\
(1.474)\end{array}$ \\
\hline Vote Share & $\begin{array}{l}-0.0001 \\
(0.002)\end{array}$ & $\begin{array}{l}-0.006 \\
(0.009)\end{array}$ & $\begin{array}{c}0.017 * * * \\
(0.004)\end{array}$ & $\begin{array}{c}0.017 \\
(0.014)\end{array}$ \\
\hline State Legislative Experience & $\begin{array}{c}0.143 \\
(0.132)\end{array}$ & $\begin{array}{c}0.095 \\
(0.465)\end{array}$ & $\begin{array}{l}-0.122 \\
(0.229)\end{array}$ & $\begin{array}{l}-1.378 \\
(0.976)\end{array}$ \\
\hline $\begin{array}{l}\text { State Legislative Experience } \\
\times \text { Professionalism }\end{array}$ & $\begin{array}{l}-0.093 \\
(0.336)\end{array}$ & $\begin{array}{c}0.736 \\
(1.148)\end{array}$ & $\begin{array}{c}0.575 \\
(0.942)\end{array}$ & $\begin{array}{c}7.218 \\
(4.629)\end{array}$ \\
\hline Constant & $\begin{array}{c}-3.636^{* * *} \\
(0.232)\end{array}$ & $\begin{array}{c}-4.537 * * * \\
(1.056) \\
\end{array}$ & $\begin{array}{c}-4.792 * * * \\
(0.373) \\
\end{array}$ & $\begin{array}{l}-3.429 * \\
(1.537) \\
\end{array}$ \\
\hline $\mathrm{N}$ & 44,619 & 634 & 25,405 & 679 \\
\hline Log likelihood & -8694.9 & -258.1 & -4257.0 & -177.6 \\
\hline Wald Chi-squared & $487.0 * * *$ & $58.3 * * *$ & $163.0^{* * *}$ & $26.0 *$ \\
\hline
\end{tabular}

Notes: Results from logit regressions, clustered by legislator, with robust standard errors in parentheses. Observations are bills sponsored the $101^{\text {st }}-109^{\text {th }}$ Congresses (1989-2006). The dependent variable takes a value of one if the bill became law. Models 4.1 and 4.2 focus on House bills (H.R.), whereas Models 4.3 and 4.4 focus on Senate bills (S.). Models 4.2 and 4.4 only include bills coming from the administration. $* p<0.05, * * p<0.01, * * * p<0.001$ (two-tailed).

Consistent with the Effective Sponsors Advance Presidential Initiatives Hypothesis, the models show that presidential initiatives become law more frequently (particularly in the House), especially when sponsored by those who were shown to sponsor such bills at a greater rate in the previous analyses. 
In all of these cases, the same types of lawmakers whom the president relies on disproportionately to advance his agenda in Congress are the ones who are more likely to convert their sponsored bills into law. With respect to the President's Bill variable, Model 4.1 demonstrates that presidential initiatives advanced in the House are more likely to become law all else equal. But such a positive relationship, while perhaps emerging in the Senate, does not attain statistical significance in Model 4.3. This finding suggests that the scope of a presidential bill's success might be more a function of the identity (and lawmaking effectiveness) of its sponsor, than the fact that it initiated with the president, per se.

Turning to 4.2 and 4.4 , which focuses solely on the collection of presidential bills, we see that presidential initiatives that are sponsored by members of the majority party are more likely to become law. However, few other variables - including a Senator's lawmaking effectiveness, as captured by her Lagged Legislative Effectiveness Score - are correlated with the probability that a bill becomes law. Similar to our analysis of the earlier lawmaking stages, it is tempting to suggest that this collection of null findings implies that being in a position of institutional influence (or an effective lawmaker, more broadly considered) does not affect whether the president's bills ultimately become law. Alternatively, it is entirely plausible that these null findings are an artifact of the sponsor selection process that the president undertakes prior to bill introduction. For example, by relying heavily on majority-party lawmakers, committee chairs, and senior lawmakers, the president has already selected an appropriate set of champions. The differentiation among them is relatively small in comparison to that between those selected as sponsors by the president and those excluded. ${ }^{19}$

\footnotetext{
${ }^{19}$ Further, in some circumstances, the difference in statistical significance between the analysis of all bills and the analysis of presidential bills is merely due to the smaller sample size presented when only looking at presidential bills. For example, the coefficient on Committee Chair is nearly identical between Models 4.1 and 4.2, whereas the standard error has tripled given the greatly reduced sample size in Model 4.2.
} 
What is very clear across all models, however, is that the president's reliance on majority-party sponsors - almost exclusively so when his party is in charge, and at the cost of his own party's members otherwise - is greatly associated with the success of his agenda in Congress. As we found in Figure 1, presidents turn to majority-party sponsors on about $60 \%$ of their initiatives when their party is in the minority. Although gaining the trust and support of such sponsors may be difficult, the payoff is enormous, as evident in the models of Table 4. For example, according to Model 4.2, the predicted success for a presidential initiative introduced in the House is $25.5 \%$ if sponsored by a majority-party lawmaker, but merely $1.4 \%$ when sponsored by a minority-party member. ${ }^{20}$ Behind these numbers are notable successes in many different policy areas, such as President Clinton working with congressional Republicans in the $104^{\text {th }}$ Congress on health care for Persian Gulf veterans (H.R. 2353), in the $105^{\text {th }}$ Congress on digital copyright issues on the emerging internet (H.R. 2281), and in the $106^{\text {th }}$ Congress on normalized trade status for China (H.R. 4444).

The above results offer somewhat mixed (but generally supportive) evidence in favor of the Effective Sponsors Advance Presidential Initiatives Hypothesis. Another way to assess the relative impact of presidents' strategic choices of sponsors in advancing their bills, however, is to consider the results of Models 3.1 and 4.1 more holistically. Because those models capture the fates of all bills - presidential and non-presidential - from all sponsors in the House, they can be used to generate predicted values under various circumstances. Most notably, holding all other variables at their means and President's Bill equal to zero gives an estimate of the fate of an average bill not initiating from the administration. In contrast, continuing to hold all other

\footnotetext{
${ }^{20}$ These predicted values are generated holding all other variables at their means (this is a conservative assumption that actually tends to understate the party differences, with no chairs or majority-party leaders being in the minority party).
} 
variables at their means, but setting President's Bill equal to one offers an estimate of what would have likely happened to presidential bills if they had been sponsored randomly by the same pool of sponsors of all other bills. Finally, those predicted values can be compared to the actual success rates of presidential bills with the strategic choice of sponsors identified above. ${ }^{21}$

Carrying out this analysis from Model 3.1 shows that the average non-presidential bill receives action in committee about $13.4 \%$ of the time. In contrast, a presidential bill, if it had a sponsor with the same average characteristics as on all other bills, would receive action in committee $34.4 \%$ of the time. This boost of more than 20 percentage points shows the attentiongrabbing nature of a proposal coming from the administration. But both of these figures are below the $46.9 \%$ of presidential bills that actually receive action in committee. The 12.5 percentage point gap between these latter two figures is based on the strategic choice of partners in Congress who sponsor and help advance the president's initiatives.

Figure 3 displays these relative degrees of success for each stage of the lawmaking process. On the left are the values described just above. Moving to the right are similarly calculated values for "action beyond committee" (from Model A3.1), for passing the House (from Model A4.1), and for becoming law (from Model 4.1). These latter values show that 4.3\% of non-presidential House bills become law. In contrast, $17.8 \%$ of presidential bills become law. The interpretation offered here suggests: about half of that boost in success rates arises simply from the bill being offered on behalf of the president; the other half is due to his strategic choice of congressional partners to carry his water in Congress, as revealed by bill sponsorship choices.

\footnotetext{
${ }^{21}$ An alternative methodological approach that simultaneously incorporates the selection mechanism into the assessment of the fate of the president's bills may be valuable.
} 


\section{Figure 3: Success of President's Bills Linked to House Sponsors}

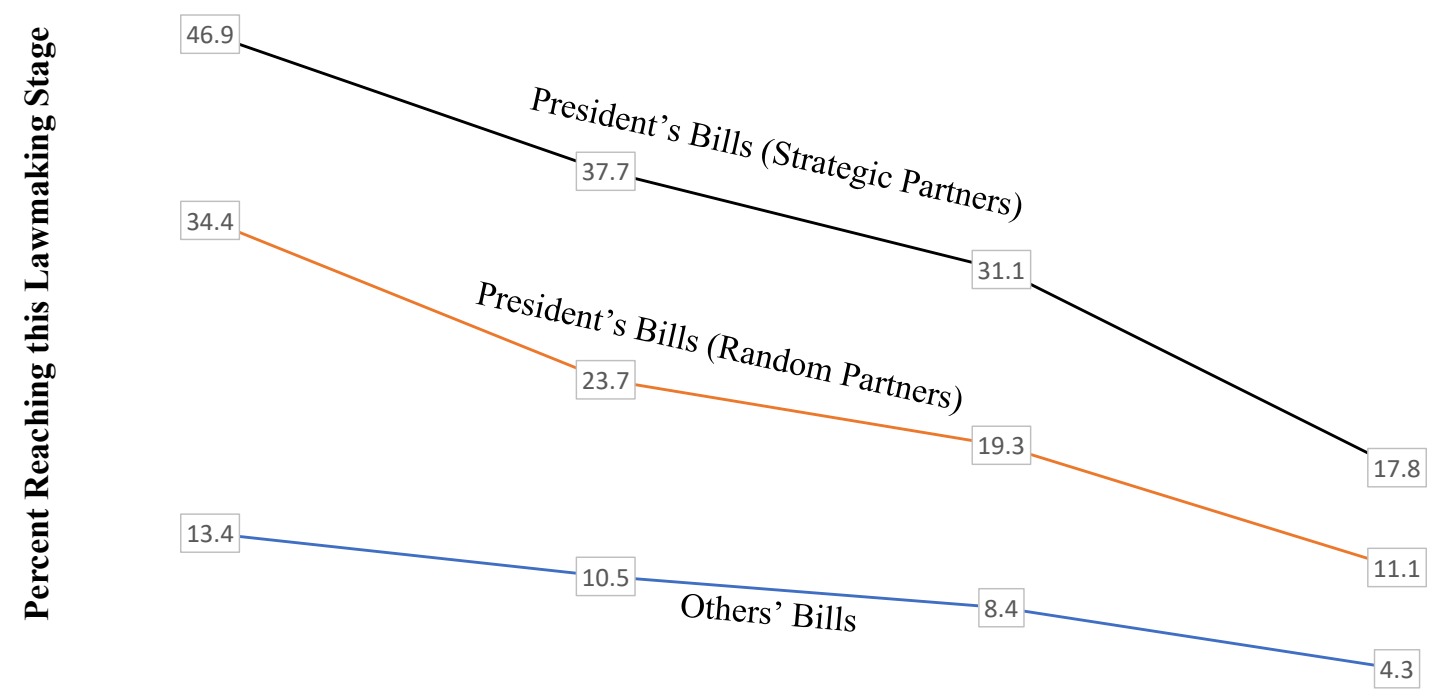

Action In Committee Action Beyond Committee

Pass House

Become Law

Notes: The figure shows the percent of bills in Congress reaching each major lawmaking stage, from receiving action in committee, to action on the floor of the House, to passing the House, and ultimately to becoming law. The bottom curve shows these averages for all bills introduced in the House other than presidential initiatives. The middle curve shows the estimated fate of presidential initiatives if the president had selected bill sponsors in the House randomly (based on expected values from Models 3.1 and 4.1 and those in the Supplemental Appendix, with President's Bill $=1$ and all other independent variables set at their means). The top curve shows the true fate of presidential initiatives based on the president's actual strategic choice of bill sponsors.

On the whole, the figure shows that about half of the boost in the success of the president's bills in the House is associated with the strategic choice of congressional partners (here as bill sponsors), consistent with the Effective Sponsors Advance Presidential Initiatives Hypothesis.

Figure 4 shows an equivalent set of calculated averages for bills introduced in the Senate.

Once again, the boost in presidential success in Congress over that for an average bill is due in

no small part to the strategic choice of sponsoring partners. Consistent with Figure 2, the success rate of Senate bills is lower in general, both for presidential and non-presidential initiatives. But presidents do succeed in their proposals at more than twice the rate of average bills in the Senate; and more than half of that boost in lawmaking success is associated with strategic partnerships evidenced in bill sponsorship decisions. 


\section{Figure 4: Success of President's Bills Linked to Senate Sponsors}

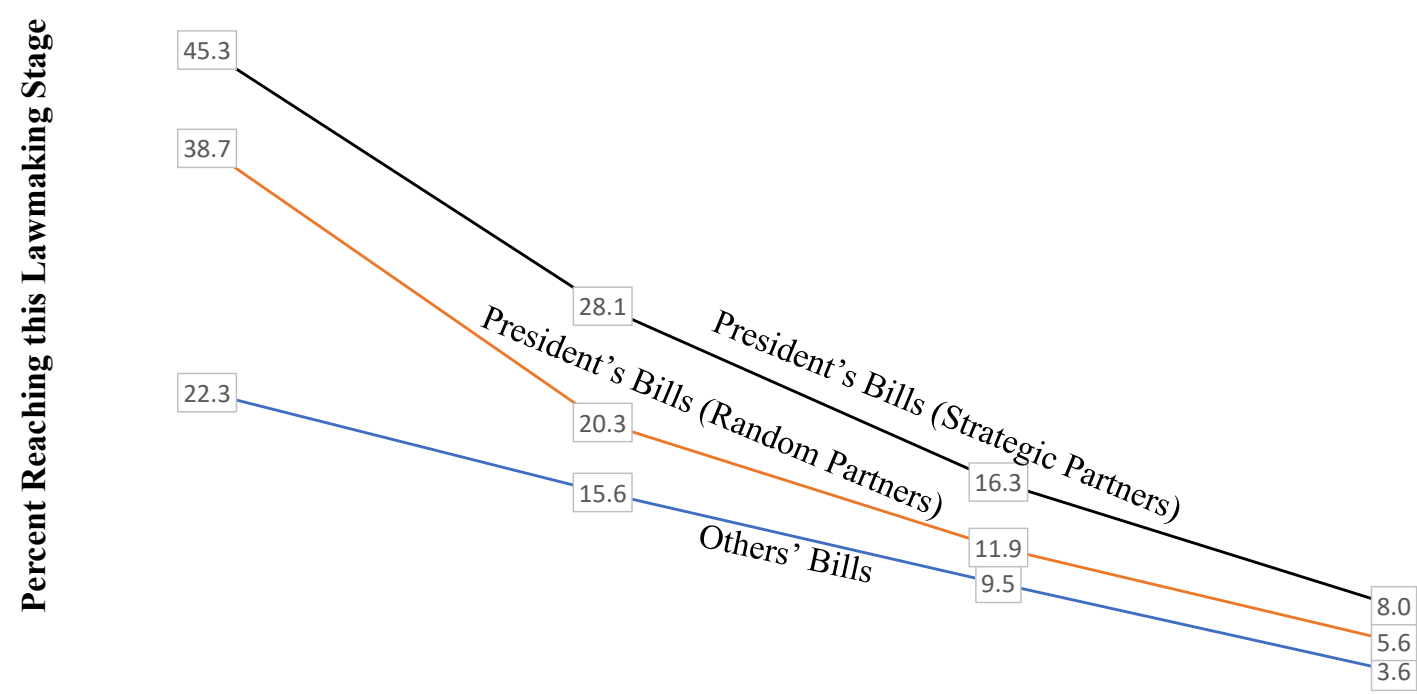

Action In Committee Action Beyond Committee

Pass Senate

Become Law

Notes: The figure shows the percent of bills in Congress reaching each major lawmaking stage, from receiving action in committee, to action on the floor of the Senate (after committee action), to passing the Senate, and ultimately to becoming law. The bottom curve shows these averages for all bills introduced in the Senate other than presidential initiatives. The middle curve shows the estimated fate of presidential initiatives if the president had selected bill sponsors in the Senate randomly (based on expected values from Models 3.3 and 4.3 and those in the Supplemental Appendix, with President's Bill $=1$ and all other independent variables set at their means). The top curve shows the true fate of presidential initiatives based on the president's actual strategic choice of bill sponsors.

On the whole, the figure shows that more than half of the boost in the success of the president's bills in the Senate (particularly in later stages) is associated with the strategic choice of congressional partners (here as bill sponsors), consistent with the Effective Sponsors Advance Presidential Initiatives Hypothesis.

On the whole, for both the House and the Senate, across every stage in the lawmaking process, while presidential bills are more likely to advance through the legislative process than non-presidential initiatives, they are even more likely to advance given the identity of the sponsors selected to advocate for his initiatives, in comparison to a randomly drawn bill sponsor. The patterns shown here therefore offer further evidence in favor of the Effective Sponsors Advance Presidential Initiatives Hypothesis. While our results suggest that there is something inherently valuable about presidential initiatives, contributing to their success, the identity of the 
sponsor - and her underlying skill and institutionally supported ability to advance legislation contributes in profound ways to the likelihood that a president's bills become law.

\section{Conclusion}

When presidents seek to change public policy, they can act unilaterally and risk the reversal of their initiatives under the next administration, or they can work with Congress to bring about more lasting changes. Dong so is difficult, but presidents are not without tools and abilities to achieve success - ranging from formal powers like the veto to informal persuasion. We highlight an important but understudied additional arrow in the president's legislative quiver. Specifically, we argue that a president's initial choice of bill sponsor on his proposals - and indeed his entire early coalition-building strategy - is enormously consequential in determining how successful his proposals will be in Congress.

Looking at over 1,400 administration bills over two decades, we find strong evidence that presidents are strategic in selecting bill sponsors. They choose to work with effective lawmakers, both in terms of the sponsors' own individual prior achievements and in their current positions as majority-party members, senior legislators, committee chairs, and party leaders. Moreover, this choice of sponsors seems to account for about half of the added legislative success of presidential proposals in the House and the Senate, relative to the counter-factual of a nonstrategic selection of early coalitional partners. Put simply, to the extent that presidents are at all effective in their lawmaking activities, the credit goes in no small part to their strategic choices in their initial interactions with members of Congress.

Rather than offering the final word on the nature and success of presidential policy activities in Congress, this work sets the stage for many additional questions to be asked and answered. First, do presidential strategies vary across presidents or over their terms in office? 
As with all complicated political tasks, experience may help presidents identify the strategies that work best for them. Our data allow scholars to examine, for example, whether a bill sponsor who brings a presidential initiative to fruition early in the president's term is more likely to be chosen as a sponsor for subsequent proposals. Additionally, our approach may allow a closer examination of relative attention to presidential initiatives when approaching a congressional midterm election than during a presidential election cycle or as a lame duck (e.g., Sullivan and de Marchi 2011).

Second, looking at various subsets of our data may offer further insights. For example, we combine proposals from administrative agencies with those directly from the president. Does the nature of the strategies surrounding these two types of initiatives differ in meaningful ways? Additionally, does the president find greater success in some issue areas than in others, and do sponsors and initial coalition partners play an outsized role in some policy areas more than in others. Also, presidents are able to have their proposals introduced as bills in either the House or the Senate. Our results suggest that presidents find a greater degree of success on their proposals in the House than those in the Senate. Why is this, and why then do presidents choose to sometimes take the more difficult path forward?

Third, although we focus on initial introductions, we know that many presidential proposals are modified in committee, on the floor, or in House-Senate negotiations. In extreme cases, the bills are changed so dramatically as to later receive a veto threat. Valuable future work could trace these legislative vehicles more fully, exploring whether bill sponsors and early proponents can keep the president's legislative priorities intact through such modifications (and how changes in bill language help or hinder the bill's progress into law). Understanding these steps is crucial to determining whether presidential goals are ultimately achieved through the 
bills that they initially propose. Incorporating the president's changing positions on these bills through his Statements of Administration Policy (SAP) may be a valuable next step (e.g., Kernell et al. 2019). Moreover, formal administrative support of some bills, as signaled in the SAP or through presidential position-taking more generally (Cohen 2019), may further boost the president's chances of legislative success.

Fourth, although we have focused on bill sponsors throughout this manuscript, those sponsors may in part serve as a proxy for a larger presidential legislative strategy being employed. Who the president seeks out as initial coalition partners is undoubtedly important, as we establish here. But those effects may extend well beyond the choice of bill sponsor. Future work that expands this coalitional information to instead study all original cosponsors of the legislation may offer additional insights into presidents' early coalition-building strategies. 


\section{References}

Anderson, William D., Janet M. Box-Steffensmeier, and Valeria Sinclair-Chapman. 2003. "The Keys to Legislative Success in the U.S. House of Representatives." Legislative Studies Quarterly 28(3): 357-386.

Battaglini, Marco, Valerio Leone Sciabolazza, and Eleonora Patacchini. 2020. "Effectiveness of Connected Legislators.” American Journal of Political Science 64(4): 739-756.

Beckmann, Matthew N. 2010. Pushing the Agenda: Presidential Leadership in U.S. Lawmaking, 1953-2004. New York: Cambridge University Press.

Bond, Jon R., and Richard Fleisher. 1990. The President in the Legislative Arena. Chicago: University of Chicago Press.

Cameron, Charles M. 2000. Veto Bargaining: Presidents and the Politics of Negative Power. New York: Cambridge University Press.

Cameron, Charles M., and Park, Jee-Kwang. 2008. "A Primer on the President's Legislative Program.” In Bert Rockman and Richard Waterman (eds.) Presidential Leadership: The Vortex of Power. New York: Oxford University Press.

Cohen, Jeffrey E. 2012. The President's Legislative Policy Agenda, 1789-2002. New York: Cambridge University Press.

Cohen, Jeffrey E. 2019. The President on Capitol Hill: A Theory of Institutional Influence. New York: Columbia University Press.

Cooper, Phillip J. 2005. "George W. Bush, Edgar Allan Poe, and the Use and Abuse of Presidential Signing Statements.” Presidential Studies Quarterly 35(3): 515-532.

Cox, Gary W., and Mathew D. McCubbins. 2005. Setting the Agenda: Responsible Party Government in the U.S. House of Representatives. New York: Cambridge University Press.

Cox, Gary W., and William C. Terry. 2008. "Legislative Productivity in the $93^{\text {rd }}-105^{\text {th }}$ Congresses.” Legislative Studies Quarterly 33(4): 603-618.

Edwards, George C., III, and Andrew Barrett. 2000. "Presidential Agenda-Setting in Congress." In Polarized Politics: Congress and the President in a Partisan Era, eds. Jon Bond and Richard Fleisher. Washington, DC: Congressional Quarterly Press, pp. 109-133.

Frantzich, Stephen. 1979. "Who Makes Our Laws? The Legislative Effectiveness of Members of the U.S. Congress." Legislative Studies Quarterly 4(3): 409-428.

Guenther, Scott M. and Samuel Kernell. 2021. "Veto Threat Bargaining with a Bicameral Congress. Political Research Quarterly 74(3): 628-644. 
Hassell, Hans J.G. and Samuel Kernell. 2016. "Veto Rhetoric and Legislative Riders." American Journal of Political Science 60(4):845-859.

Kernell, Samuel. 2006. Going Public: New Strategies of Presidential Leadership (4th ed.). Washington, D.C.: CQ Press.

Kernell, Samuel, Roger Larocca, Huchen Liu, and Andrew Rudalevige. 2019. "New Data for Investigating the President's Legislative Program: OMB Logs and SAPs.” Presidential Studies Quarterly 49(2): 330-357.

Larocca, Roger T. 2006. The Presidential Agenda: Sources of Executive Influence in Congress. Columbus, OH: Ohio State University Press.

Light, Paul C. 1991. The President's Agenda. Baltimore: Johns Hopkins University Press.

Malbin, Michael J. 2001. "Presidential Proposals to Congress and Related Roll Call Votes, 17891993.” In Elaine K. Swift et al. Database of Congressional Historical Statistics, 1789-1988 [computer file] Ann Arbor, MI: ICPSR. 2001.

Matthews, Donald R. 1960. U.S. Senators and Their World. Chapel Hill: University of North Carolina Press.

Mayer, Kenneth R. 1999. "Executive Orders and Presidential Power.” Journal of Politics 61(2): 445-466.

Mayhew, David R. 1991. Divided We Govern. New Haven: Yale University Press.

Moe, Terry, and William G. Howell. 1999. "The Presidential Power of Unilateral Action." Journal of Law, Economics, and Organization 15(1): 132-179.

Montgomery, Jacob M., and Brendan Nyhan. 2017. "The Effects of Congressional Staff Networks in the U.S. House of Representatives." Journal of Politics 79(3): 745-761.

Nelson, Michael, and Barbara A. Perry. 2014. 41: Inside the Presidency of George H.W. Bush. Ithaca, NY: Cornell University Press.

Neustadt, Richard. 1960. Presidential Power and the Modern Presidents. New York: Free Press.

Peterson, Mark A. 1990. Legislating Together: The White House and Capitol Hill from Eisenhower to Reagan. Washington, D.C.: The Brookings Institution.

Rudalevige, Andrew. 2002. Managing the President's Program: Presidential Leadership and Legislative Policy Formulation. Princeton, NJ: Princeton University Press. 
Sinclair, Barbara. 2014. "The Offered Hand and the Veto Fist." In Nelson and Perry (eds.), 41: Inside the Presidency of George H.W. Bush. Ithaca, NY: Cornell University Press.

Sullivan, Terry, and Scott de Marchi. 2011. "Congressional Bargaining in Presidential Time: Give and Take, Anticipation, and the Constitutional Rationalization of Dead Ducks." Journal of Politics 73(3): 748-763.

Thrower, Sharece D. 2017. "To Revoke or Not Revoke? The Political Determinants of Executive Order Longevity." American Journal of Political Science 61(3): 642-656.

Volden, Craig, and Alan E. Wiseman. 2014. Legislative Effectiveness in the United States Congress: The Lawmakers. New York: Cambridge University Press.

Volden, Craig, and Alan E. Wiseman. 2018. "Legislative Effectiveness in the United States Senate.” Journal of Politics 80(2): 731-735.

Weinberg, Jeffrey A. 2018. "The View from the Oval Office: Understanding the Legisaltive Presidency," Journal of Legislative Studies 24(4): 395-412.

Wiseman, Alan E. 2009. "Delegation and Positive-Sum Bureaucracies." Journal of Politics 71(3): 998-1014.

Woodward, Bob. 1994. The Agenda: Inside the Clinton White House. New York: Simon \& Schuster Press. 


\section{Supplemental Appendix}

Table A1: Descriptive Statistics, Variable Definitions, and Sources (Bill Sponsor Analyses)

\begin{tabular}{|c|c|c|c|}
\hline Variable & Description & $\begin{array}{l}\text { House } \\
\text { Mean } \\
\text { (S.D.) }\end{array}$ & $\begin{array}{l}\text { Senate } \\
\text { Mean } \\
\text { (S.D.) }\end{array}$ \\
\hline $\begin{array}{l}\text { Number of Presidential } \\
\text { Bills Sponsored }\end{array}$ & $\begin{array}{l}\text { Number of bills sponsored by this lawmaker whose } \\
\text { origins are with the president or his administration }\end{array}$ & $\begin{array}{c}0.175 \\
(0.694)\end{array}$ & $\begin{array}{c}0.806 \\
(2.545)\end{array}$ \\
\hline President's Party ${ }^{\mathrm{b}}$ & $\begin{array}{c}1=\text { Lawmaker is a member of the president's party; } 0 \\
=\text { otherwise }\end{array}$ & $\begin{array}{c}0.482 \\
(0.500)\end{array}$ & $\begin{array}{l}0.483 \\
(0.500)\end{array}$ \\
\hline Majority Party ${ }^{b}$ & $1=$ Majority party member; $0=$ otherwise & $\begin{array}{c}0.542 \\
(0.498)\end{array}$ & $\begin{array}{c}0.542 \\
(0.499)\end{array}$ \\
\hline Committee Chair $^{\mathrm{b}}$ & $1=$ Committee chair; $0=$ otherwise & $\begin{array}{c}0.049 \\
(0.216)\end{array}$ & $\begin{array}{c}0.160 \\
(0.367)\end{array}$ \\
\hline Subcommittee Chair ${ }^{\mathrm{b}}$ & $1=$ Subcommittee chair; $0=$ otherwise & $\begin{array}{c}0.218 \\
(0.413)\end{array}$ & $\begin{array}{c}0.420 \\
(0.494)\end{array}$ \\
\hline $\begin{array}{l}\text { Majority-Party } \\
\text { Leadership }\end{array}$ & $\begin{array}{c}1=\text { In majority party leadership position; } 0= \\
\text { otherwise }\end{array}$ & $\begin{array}{c}0.018 \\
(0.134)\end{array}$ & $\begin{array}{c}0.055 \\
(0.229)\end{array}$ \\
\hline $\begin{array}{l}\text { Minority-Party } \\
\text { Leadership }^{\mathrm{b}}\end{array}$ & $\begin{array}{c}1=\text { In minority party leadership position; } 0= \\
\text { otherwise }\end{array}$ & $\begin{array}{c}0.020 \\
(0.139)\end{array}$ & $\begin{array}{c}0.046 \\
(0.209)\end{array}$ \\
\hline Speaker ${ }^{b}$ & $1=$ Speaker of the House; $0=$ otherwise & $\begin{array}{c}0.002 \\
(0.050)\end{array}$ & $\mathrm{N} / \mathrm{A}$ \\
\hline $\begin{array}{l}\text { Lagged Legislative } \\
\text { Effectiveness Score }\end{array}$ & $\begin{array}{l}\text { Legislative Effectiveness Score of lawmaker in } \\
\text { previous Congress }\end{array}$ & $\begin{array}{c}0.999 \\
(1.568)\end{array}$ & $\begin{array}{l}1.005 \\
(1.001)\end{array}$ \\
\hline Seniority $^{\mathrm{b}}$ & $\begin{array}{c}\text { Count of number of two-year Congresses that } \\
\text { member served in }\end{array}$ & $\begin{array}{c}5.334 \\
(3.970)\end{array}$ & $\begin{array}{c}6.529 \\
(4.678)\end{array}$ \\
\hline Power Committee ${ }^{b}$ & $\begin{array}{c}1=\text { member sits on one of the top committees; } 0= \\
\text { otherwise }\end{array}$ & $\begin{array}{l}0.256 \\
(0.436)\end{array}$ & $\begin{array}{c}0.719 \\
(0.450)\end{array}$ \\
\hline Female $^{\mathrm{b}}$ & $1=$ member is female; $0=$ male & $\begin{array}{l}0.116 \\
(0.320)\end{array}$ & $\begin{array}{l}0.087 \\
(0.281)\end{array}$ \\
\hline African American ${ }^{\mathrm{b}}$ & $1=$ member is African American; $0=$ otherwise & $\begin{array}{c}0.083 \\
(0.276)\end{array}$ & $\begin{array}{c}0.004 \\
(0.067)\end{array}$ \\
\hline Latino $^{\mathrm{b}}$ & $1=$ member is Latino/Latina; $0=$ otherwise & $\begin{array}{l}0.046 \\
(0.209)\end{array}$ & $\begin{array}{c}0.002 \\
(0.047)\end{array}$ \\
\hline Distance from Median ${ }^{\mathrm{c}}$ & $\begin{array}{l}\text { Absolute distance from member's first-dimension } \\
\text { DW-NOMINATE Score to that of floor median }\end{array}$ & $\begin{array}{c}0.364 \\
(0.212)\end{array}$ & $\begin{array}{c}0.320 \\
(0.171)\end{array}$ \\
\hline Vote Share ${ }^{b}$ & Percent vote share in most recent election & $\begin{array}{c}68.19 \\
(13.55)\end{array}$ & $\begin{array}{l}59.90 \\
(9.24)\end{array}$ \\
\hline $\begin{array}{l}\text { State Legislative } \\
\text { Experience }^{\mathrm{b}}\end{array}$ & $\begin{array}{c}\begin{array}{c}1=\text { member previously served in state legislature; } 0 \\
=\text { otherwise }\end{array}\end{array}$ & $\begin{array}{c}0.514 \\
(0.500)\end{array}$ & $\begin{array}{c}0.391 \\
(0.488)\end{array}$ \\
\hline $\begin{array}{l}\text { State Legislative } \\
\text { Experience } \times \\
\text { Professionalism }^{\mathrm{b}}\end{array}$ & $\begin{array}{l}\text { Interaction of State Legislative Experience variable } \\
\text { and Squire metric of legislative professionalism in } \\
\text { that state }\end{array}$ & $\begin{array}{c}0.152 \\
(0.185)\end{array}$ & $\begin{array}{c}0.079 \\
(0.115)\end{array}$ \\
\hline
\end{tabular}

Sources:

${ }^{\mathrm{a}}$ Constructed by authors as described in the text.

${ }^{\mathrm{b}}$ Constructed by authors from data available at www.thelawmakers.org.

${ }^{\mathrm{c} C o n s t r u c t e d ~ b y ~ a u t h o r s ~ f r o m ~ d a t a ~ a v a i l a b l e ~ a t ~ w w w . v o t e v i e w . c o m . ~}$ 
Table A2: Descriptive Statistics, Variable Definitions, and Sources (Bill-Level Analyses)

\begin{tabular}{|c|c|c|c|}
\hline Variable & Description & $\begin{array}{l}\text { House } \\
\text { Mean } \\
\text { (S.D.) }\end{array}$ & $\begin{array}{l}\text { Senate } \\
\text { Mean } \\
\text { (S.D.) }\end{array}$ \\
\hline President's Billa $^{\mathrm{a}}$ & $\begin{array}{c}1=\text { Bill was initiative of president or his } \\
\text { administration; } 0=\text { otherwise }\end{array}$ & $\begin{array}{c}0.014 \\
(0.118)\end{array}$ & $\begin{array}{c}0.027 \\
(0.161)\end{array}$ \\
\hline Action In Committee ${ }^{b}$ & $1=$ Bill received action in committee; $0=$ otherwise & $\begin{array}{c}0.159 \\
(0.366)\end{array}$ & $\begin{array}{c}0.234 \\
(0.423)\end{array}$ \\
\hline Became Law ${ }^{b}$ & $1=$ Bill became law; $0=$ otherwise & $\begin{array}{c}0.053 \\
(0.224)\end{array}$ & $\begin{array}{l}0.041 \\
(0.197)\end{array}$ \\
\hline Majority Party & $\begin{array}{c}1=\text { Bill sponsored by majority party member; } 0= \\
\text { otherwise }\end{array}$ & $\begin{array}{c}0.590 \\
(0.492)\end{array}$ & $\begin{array}{c}0.585 \\
(0.493)\end{array}$ \\
\hline Committee Chair ${ }^{b}$ & $1=$ Bill sponsored by committee chair; $0=$ otherwise & $\begin{array}{c}0.087 \\
(0.281)\end{array}$ & $\begin{array}{c}0.222 \\
(0.416)\end{array}$ \\
\hline Subcommittee Chair ${ }^{\mathrm{b}}$ & $\begin{array}{c}1=\text { Bill sponsored by subcommittee chair; } 0= \\
\text { otherwise }\end{array}$ & $\begin{array}{c}0.287 \\
(0.452)\end{array}$ & $\begin{array}{c}0.461 \\
(0.498)\end{array}$ \\
\hline $\begin{array}{l}\text { Majority-Party } \\
\text { Leadership }^{\mathrm{b}}\end{array}$ & $\begin{array}{c}1=\text { Bill sponsored by member in majority party } \\
\text { leadership position; } 0=\text { otherwise }\end{array}$ & $\begin{array}{c}0.014 \\
(0.117)\end{array}$ & $\begin{array}{l}0.056 \\
(0.229)\end{array}$ \\
\hline $\begin{array}{l}\text { Minority-Party } \\
\text { Leadership }\end{array}$ & $\begin{array}{c}1=\text { Bill sponsored by member in minority party } \\
\text { leadership position; } 0=\text { otherwise }\end{array}$ & $\begin{array}{c}0.015 \\
(0.121)\end{array}$ & $\begin{array}{c}0.043 \\
(0.204)\end{array}$ \\
\hline Speaker $^{\mathrm{b}}$ & $\begin{array}{c}1=\text { Bill sponsored by Speaker of the House; } 0= \\
\text { otherwise }\end{array}$ & $\begin{array}{l}0.0005 \\
(0.023)\end{array}$ & $\mathrm{N} / \mathrm{A}$ \\
\hline $\begin{array}{l}\text { Lagged Legislative } \\
\text { Effectiveness Score }\end{array}$ & $\begin{array}{l}\text { Legislative Effectiveness Score of bill sponsor in } \\
\text { previous Congress }\end{array}$ & $\begin{array}{l}1.452 \\
(2.107)\end{array}$ & $\begin{array}{l}1.236 \\
(1.177)\end{array}$ \\
\hline Seniority ${ }^{\mathrm{b}}$ & $\begin{array}{c}\text { Count of number of two-year Congresses that bill } \\
\text { sponsor served in }\end{array}$ & $\begin{array}{c}6.139 \\
(4.090)\end{array}$ & $\begin{array}{c}7.075 \\
(4.670)\end{array}$ \\
\hline Power Committee ${ }^{b}$ & $\begin{array}{c}1=\text { Bill sponsored by member who sits on one of the } \\
\text { top committees; } 0=\text { otherwise }\end{array}$ & $\begin{array}{c}0.254 \\
(0.436)\end{array}$ & $\begin{array}{c}0.752 \\
(0.432)\end{array}$ \\
\hline Female $^{\mathrm{b}}$ & $1=$ Bill sponsor is female; $0=$ male & $\begin{array}{c}0.129 \\
(0.336)\end{array}$ & $\begin{array}{c}0.099 \\
(0.298)\end{array}$ \\
\hline African American ${ }^{\mathrm{b}}$ & $1=$ Bill sponsor is African American; $0=$ otherwise & $\begin{array}{c}0.069 \\
(0.254)\end{array}$ & $\begin{array}{c}0.004 \\
(0.062)\end{array}$ \\
\hline Latino $^{\mathrm{b}}$ & $1=$ Bill sponsor is Latino/Latina; $0=$ otherwise & $\begin{array}{c}0.034 \\
(0.181)\end{array}$ & $\begin{array}{l}0.003 \\
(0.051)\end{array}$ \\
\hline Distance from Median ${ }^{c}$ & $\begin{array}{l}\text { Absolute distance from bill sponsor's first-dimension } \\
\text { DW-NOMINATE Score to that of floor median }\end{array}$ & $\begin{array}{c}0.353 \\
(0.217)\end{array}$ & $\begin{array}{c}0.305 \\
(0.169)\end{array}$ \\
\hline Vote Share $^{\mathrm{b}}$ & $\begin{array}{l}\text { Percent vote share received by bill sponsor in most } \\
\text { recent election }\end{array}$ & $\begin{array}{c}68.87 \\
(13.16)\end{array}$ & $\begin{array}{l}59.80 \\
(8.77)\end{array}$ \\
\hline $\begin{array}{l}\text { State Legislative } \\
\text { Experience }^{\mathrm{b}}\end{array}$ & $\begin{array}{c}1=\text { Bill sponsor previously served in state } \\
\text { legislature; } 0=\text { otherwise }\end{array}$ & $\begin{array}{l}0.509 \\
(0.500)\end{array}$ & $\begin{array}{c}0.377 \\
(0.485)\end{array}$ \\
\hline $\begin{array}{l}\text { State Legislative } \\
\text { Experience } \times \\
\text { Professionalism }^{\mathrm{b}}\end{array}$ & $\begin{array}{c}\text { Interaction of State Legislative Experience variable } \\
\text { and Squire metric of legislative professionalism in } \\
\text { that state }\end{array}$ & $\begin{array}{c}0.154 \\
(0.187)\end{array}$ & $\begin{array}{c}0.081 \\
(0.121)\end{array}$ \\
\hline
\end{tabular}

Sources:

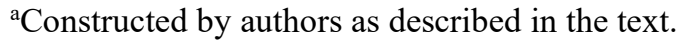

${ }^{\mathrm{b}}$ Constructed by authors from data available at www.thelawmakers.org.

${ }^{\mathrm{c} C}$ Constructed by authors from data available at www.voteview.com. 


\begin{tabular}{|c|c|c|c|c|}
\hline $\begin{array}{l}\text { DV: Bill Received "Action } \\
\text { Beyond Committee" }\end{array}$ & $\begin{array}{c}\text { Model A3.1: } \\
\text { House } \\
\text { All Bills }\end{array}$ & $\begin{array}{c}\text { Model A3.2: } \\
\text { House } \\
\text { President's Bills }\end{array}$ & $\begin{array}{c}\text { Model A3.3: } \\
\text { Senate } \\
\text { All Bills }\end{array}$ & $\begin{array}{c}\text { Model A3.4: } \\
\text { Senate } \\
\text { President's Bills }\end{array}$ \\
\hline President's Bill & $\begin{array}{l}0.973 * * * \\
(0.143)\end{array}$ & & $\begin{array}{c}0.319 \\
(0.234)\end{array}$ & \\
\hline Majority Party & $\begin{array}{c}0.872 * * * \\
(0.126)\end{array}$ & $\begin{array}{c}2.889 * * * \\
(0.565)\end{array}$ & $\begin{array}{c}0.722 * * * \\
(0.137)\end{array}$ & $\begin{array}{c}2.784 * * * \\
(0.592)\end{array}$ \\
\hline Committee Chair & $\begin{array}{l}0.823 * * * \\
(0.116)\end{array}$ & $\begin{array}{l}0.869^{*} \\
(0.436)\end{array}$ & $\begin{array}{l}0.514 * * * \\
(0.094)\end{array}$ & $\begin{array}{l}-0.398 \\
(0.437)\end{array}$ \\
\hline Subcommittee Chair & $\begin{array}{c}0.323 * * * \\
(0.075)\end{array}$ & $\begin{array}{l}-0.055 \\
(0.330)\end{array}$ & $\begin{array}{l}-0.106 \\
(0.091)\end{array}$ & $\begin{array}{l}-0.851 * \\
(0.337)\end{array}$ \\
\hline Majority Party Leadership & $\begin{array}{c}0.586 * * * \\
(0.138)\end{array}$ & $\begin{array}{c}2.324 * * \\
(0.852)\end{array}$ & $\begin{array}{l}-0.013 \\
(0.170)\end{array}$ & $\begin{array}{r}-0.710 \\
(0.468)\end{array}$ \\
\hline Minority Party Leadership & $\begin{array}{l}-0.148 \\
(0.258)\end{array}$ & & $\begin{array}{l}-0.177 \\
(0.168)\end{array}$ & $\begin{array}{l}-1.017 \\
(1.128)\end{array}$ \\
\hline Speaker & $\begin{array}{c}1.477 \\
(0.788)\end{array}$ & & & \\
\hline $\begin{array}{l}\text { Lagged Legislative } \\
\text { Effectiveness Score }\end{array}$ & $\begin{array}{c}0.075^{* * *} \\
(0.012)\end{array}$ & $\begin{array}{l}-0.068 \\
(0.046)\end{array}$ & $\begin{array}{l}0.066^{* *} \\
(0.027)\end{array}$ & $\begin{array}{l}-0.223 \\
(0.151)\end{array}$ \\
\hline Seniority & $\begin{array}{c}0.010 \\
(0.011)\end{array}$ & $\begin{array}{l}-0.027 \\
(0.030)\end{array}$ & $\begin{array}{c}0.012 \\
(0.012)\end{array}$ & $\begin{array}{l}-0.048 \\
(0.043)\end{array}$ \\
\hline Power Committee & $\begin{array}{c}-0.301 * * * \\
(0.091)\end{array}$ & $\begin{array}{c}0.331 \\
(0.310)\end{array}$ & $\begin{array}{c}-0.334 * * * \\
(0.088)\end{array}$ & $\begin{array}{l}-0.160 \\
(0.302)\end{array}$ \\
\hline Female & $\begin{array}{c}-0.319 * * \\
(0.102)\end{array}$ & $\begin{array}{l}-0.750 \\
(0.897)\end{array}$ & $\begin{array}{l}-0.122 \\
(0.205)\end{array}$ & $\begin{array}{c}1.902 * * * \\
(0.503)\end{array}$ \\
\hline African American & $\begin{array}{c}0.192 \\
(0.144)\end{array}$ & $\begin{array}{l}-0.883 \\
(0.486)\end{array}$ & $\begin{array}{l}-0.046 \\
(0.233)\end{array}$ & \\
\hline Latino & $\begin{array}{l}0.415^{*} \\
(0.172)\end{array}$ & $\begin{array}{l}-0.645 \\
(0.486)\end{array}$ & & \\
\hline Distance from Median & $\begin{array}{l}-0.406 \\
(0.254)\end{array}$ & $\begin{array}{c}1.796 \\
(1.092)\end{array}$ & $\begin{array}{l}-0.169 \\
(0.321)\end{array}$ & $\begin{array}{l}-1.273 \\
(1.409)\end{array}$ \\
\hline Vote Share & $\begin{array}{l}0.0001 \\
(0.002)\end{array}$ & $\begin{array}{l}-0.026^{* *} \\
(0.008)\end{array}$ & $\begin{array}{l}0.019 * * * \\
(0.004)\end{array}$ & $\begin{array}{c}0.006 \\
(0.013)\end{array}$ \\
\hline State Legislative Experience & $\begin{array}{c}0.052 \\
(0.122)\end{array}$ & $\begin{array}{c}0.115 \\
(0.454)\end{array}$ & $\begin{array}{c}0.047 \\
(0.179)\end{array}$ & $\begin{array}{l}-1.574 \\
(0.822)\end{array}$ \\
\hline $\begin{array}{l}\text { State Legislative Experience } \\
\times \text { Professionalism }\end{array}$ & $\begin{array}{c}0.119 \\
(0.316)\end{array}$ & $\begin{array}{c}0.266 \\
(1.132)\end{array}$ & $\begin{array}{c}0.009 \\
(0.732)\end{array}$ & $\begin{array}{l}8.283^{*} \\
(3.537)\end{array}$ \\
\hline Constant & $\begin{array}{c}-2.829 * * * \\
(0.212)\end{array}$ & $\begin{array}{c}-1.336 \\
(0.773)\end{array}$ & $\begin{array}{c}-3.149 * * * \\
(0.304)\end{array}$ & $\begin{array}{l}-1.394 \\
(1.175)\end{array}$ \\
\hline $\mathrm{N}$ & 44,619 & 634 & 25,434 & 719 \\
\hline $\begin{array}{l}\text { Log likelihood } \\
\text { Wald Chi-squared }\end{array}$ & $\begin{array}{l}-15,659.0 \\
768.7 * * *\end{array}$ & $\begin{array}{c}-338.4 \\
83.8 * * *\end{array}$ & $\begin{array}{l}-11,069.5 \\
338.7 * * *\end{array}$ & $\begin{array}{c}-363.2 \\
60.6^{* * *}\end{array}$ \\
\hline
\end{tabular}

Notes: Results from logit regressions, clustered by legislator, with robust standard errors in parentheses. Observations are bills sponsored the $101^{\text {st }}-109^{\text {th }}$ Congresses $(1989-2006)$. Dependent variable takes value of one if bills received action beyond committee, reaching the floor of the House or Senate. Models A3.1 and A3.2 focus on House bills (H.R.), whereas Models A3.3 and A3.4 focus on Senate bills (S.). Models A3.2 and A3.4 only include bills coming from the administration.

$* p<0.05, * * p<0.01, * * * p<0.001$ (two-tailed).

Consistent with the Effective Sponsors Advance Presidential Initiatives Hypothesis, the models show that presidential initiatives find their way through committee and onto the floor at a higher rate (particularly in the House), especially when sponsored by those who were shown to sponsor such bills at a greater rate in the previous analyses. 


\begin{tabular}{|c|c|c|c|c|}
\hline $\begin{array}{l}\text { DV: Bill Passed Home } \\
\text { Chamber }\end{array}$ & $\begin{array}{l}\text { Model A4.1: } \\
\text { House } \\
\text { All Bills }\end{array}$ & $\begin{array}{c}\text { Model A4.2: } \\
\text { House } \\
\text { President's Bills }\end{array}$ & $\begin{array}{c}\text { Model A4.3: } \\
\text { Senate } \\
\text { All Bills }\end{array}$ & $\begin{array}{l}\text { Model A4.4: } \\
\text { Senate } \\
\text { President's Bills }\end{array}$ \\
\hline President's Bill & $\begin{array}{c}0.954 * * * \\
(0.136)\end{array}$ & & $\begin{array}{c}0.259 \\
(0.218)\end{array}$ & \\
\hline Majority Party & $\begin{array}{c}0.844 * * * \\
(0.128)\end{array}$ & $\begin{array}{c}3.207 * * * \\
(0.670)\end{array}$ & $\begin{array}{l}0.436^{* *} \\
(0.161)\end{array}$ & $\begin{array}{l}1.780 * * \\
(0.628)\end{array}$ \\
\hline Committee Chair & $\begin{array}{c}0.692 * * * \\
(0.106)\end{array}$ & $\begin{array}{c}0.689 \\
(0.438)\end{array}$ & $\begin{array}{c}0.411 * * * \\
(0.106)\end{array}$ & $\begin{array}{c}0.515 \\
(0.415)\end{array}$ \\
\hline Subcommittee Chair & $\begin{array}{c}0.285^{* * * *} \\
(0.076)\end{array}$ & $\begin{array}{c}0.105 \\
(0.330)\end{array}$ & $\begin{array}{l}-0.038 \\
(0.107)\end{array}$ & $\begin{array}{l}-0.719 * \\
(0.360)\end{array}$ \\
\hline Majority Party Leadership & $\begin{array}{c}0.655^{* * *} \\
(0.140)\end{array}$ & $\begin{array}{l}1.643^{* *} \\
(0.611)\end{array}$ & $\begin{array}{c}0.038 \\
(0.165)\end{array}$ & $\begin{array}{r}-0.422 \\
(0.652)\end{array}$ \\
\hline Minority Party Leadership & $\begin{array}{l}-0.067 \\
(0.265)\end{array}$ & & $\begin{array}{l}-0.084 \\
(0.189)\end{array}$ & $\begin{array}{l}-1.182 \\
(0.985)\end{array}$ \\
\hline Speaker & $\begin{array}{l}1.666^{*} \\
(0.784)\end{array}$ & & & \\
\hline $\begin{array}{l}\text { Lagged Legislative } \\
\text { Effectiveness Score }\end{array}$ & $\begin{array}{c}0.064 * * * \\
(0.014)\end{array}$ & $\begin{array}{l}-0.036 \\
(0.049)\end{array}$ & $\begin{array}{l}0.095^{* *} \\
(0.030)\end{array}$ & $\begin{array}{l}-0.224 \\
(0.146)\end{array}$ \\
\hline Seniority & $\begin{array}{l}0.009 \\
(0.011)\end{array}$ & $\begin{array}{l}-0.024 \\
(0.032)\end{array}$ & $\begin{array}{c}-0.00001 \\
(0.013)\end{array}$ & $\begin{array}{l}-0.079 \\
(0.042)\end{array}$ \\
\hline Power Committee & $\begin{array}{l}-0.232 * \\
(0.092)\end{array}$ & $\begin{array}{c}0.450 \\
(0.320)\end{array}$ & $\begin{array}{c}-0.300^{* * *} \\
(0.093)\end{array}$ & $\begin{array}{l}-0.266 \\
(0.324)\end{array}$ \\
\hline Female & $\begin{array}{c}-0.364 * * * \\
(0.108)\end{array}$ & $\begin{array}{l}-0.512 \\
(0.744)\end{array}$ & $\begin{array}{l}-0.138 \\
(0.190)\end{array}$ & $\begin{array}{c}0.629 \\
(0.467)\end{array}$ \\
\hline African American & $\begin{array}{c}0.279 \\
(0.158)\end{array}$ & $\begin{array}{l}-1.438^{*} \\
(0.711)\end{array}$ & $\begin{array}{l}-0.297 \\
(0.230)\end{array}$ & \\
\hline Latino & $\begin{array}{l}0.444^{* *} \\
(0.154)\end{array}$ & $\begin{array}{l}-0.382 \\
(0.544)\end{array}$ & & \\
\hline Distance from Median & $\begin{array}{l}-0.416 \\
(0.258)\end{array}$ & $\begin{array}{l}2.480^{*} \\
(1.132)\end{array}$ & $\begin{array}{l}-0.214 \\
(0.364)\end{array}$ & $\begin{array}{c}0.013 \\
(1.238)\end{array}$ \\
\hline Vote Share & $\begin{array}{l}0.0002 \\
(0.002)\end{array}$ & $\begin{array}{l}-0.015 \\
(0.008)\end{array}$ & $\begin{array}{c}0.022 * * * \\
(0.005)\end{array}$ & $\begin{array}{c}0.007 \\
(0.013)\end{array}$ \\
\hline State Legislative Experience & $\begin{array}{c}0.151 \\
(0.116)\end{array}$ & $\begin{array}{l}0.341 \\
(0.455)\end{array}$ & $\begin{array}{c}0.143 \\
(0.202)\end{array}$ & $\begin{array}{l}-1.648^{*} \\
(0.772)\end{array}$ \\
\hline $\begin{array}{l}\text { State Legislative Experience } \\
\quad \times \text { Professionalism }\end{array}$ & $\begin{array}{l}-0.055 \\
(0.300)\end{array}$ & $\begin{array}{l}-0.313 \\
(1.078)\end{array}$ & $\begin{array}{l}-0.476 \\
(0.858)\end{array}$ & $\begin{array}{l}8.205^{*} \\
(3.377)\end{array}$ \\
\hline Constant & $\begin{array}{c}-3.058^{* * *} \\
(0.212)\end{array}$ & $\begin{array}{c}-3.126^{* * *} \\
(0.827)\end{array}$ & $\begin{array}{c}-3.749 * * * \\
(0.329)\end{array}$ & $\begin{array}{l}-1.911 \\
(1.226)\end{array}$ \\
\hline $\mathrm{N}$ & 44,619 & 634 & 25,434 & 719 \\
\hline Log likelihood & $-13,792.6$ & -325.2 & $-8,185.4$ & -289.2 \\
\hline Wald Chi-squared & $700.0 * * *$ & $68.6^{* * *}$ & $181.0^{* * *}$ & $41.8^{* * *}$ \\
\hline
\end{tabular}

Notes: Results from logit regressions, clustered by legislator, with robust standard errors in parentheses. Observations are bills sponsored the $101^{\text {st }}-109^{\text {th }}$ Congresses (1989-2006). Dependent variable takes value of one if bill passed home chamber of Congress. Models A4.1 and A4.2 focus on House bills (H.R.), whereas Models A4.3 and A4.4 focus on Senate bills (S.). Models A4.2 and A4.4 only include bills coming from the administration.

$* p<0.05, * * p<0.01, * * * p<0.001$ (two-tailed).

Consistent with the Effective Sponsors Advance Presidential Initiatives Hypothesis, the models show that presidential initiatives pass their home chambers at a higher rate (particularly in the House), especially when sponsored by those who were shown to sponsor such bills at a greater rate in the previous analyses. 
Table B1: Number of Executive-Authored House Bills Identified by Our Three Sources

\begin{tabular}{|c|c|c|c|c|c|c|}
\hline & \multicolumn{3}{|c|}{ Transmitting Agency } & \multicolumn{3}{c|}{ Data Source } \\
\hline Congress & $\begin{array}{c}\text { Presidential } \\
\text { transmission }\end{array}$ & $\begin{array}{c}\text { Executive } \\
\text { agency }\end{array}$ & $\begin{array}{c}\text { Independent } \\
\text { agency }\end{array}$ & $\begin{array}{c}\text { Bills in } \\
\text { OMB } \\
\text { logs }\end{array}$ & $\begin{array}{c}\text { Bills in executive } \\
\text { communications }\end{array}$ & $\begin{array}{c}\text { Bills } \\
\text { introduced } \\
\text { "by request" }\end{array}$ \\
\hline 101 st & 14 & 122 & 16 & 101 & 123 & 137 \\
\hline 102 nd & 14 & 185 & 5 & 71 & 92 & 194 \\
\hline 103 rd & 16 & 91 & 9 & 90 & 98 & 113 \\
\hline 104 th & 10 & 87 & 7 & 79 & 80 & 57 \\
\hline 105 th & 5 & 72 & 2 & 44 & 65 & 48 \\
\hline 106 th & 4 & 71 & 4 & 44 & 60 & 29 \\
\hline 107 th & 6 & 27 & 2 & 20 & 19 & 16 \\
\hline 108 th & 5 & 38 & 0 & 27 & 14 & 18 \\
\hline 109 th & 1 & 30 & 1 & 12 & 23 & 12 \\
\hline
\end{tabular}

The table shows the number of presidential bills introduced in the House in each Congress, as detected through each of our three sources (OMB logs, Executive Communications, and "by request"), as described in the text.

As shown in the third column of Table B1, independent agencies also author bills and transmit them to Congress, but we do not include these bills as presidential bills for multiple reasons. First, independent agencies are designed to be insulated from political influence by statutory provisions that protect political appointees from termination except for cause. Second, many independent agencies are given specific statutory "bypass" authority to send legislative proposals directly to Congress, rather than through OMB's clearance process (Wiseman 2009). OMB acknowledges that some independent agencies claim an informal bypass authority, and it has made no attempt to force agencies that claim statutory or informal bypass authority to comply with legislative clearance. Sometimes, independent agencies with statutory or informal bypass authority nevertheless submit legislative proposals for OMB clearance. Since some of these bills receive "in accord" or "consistent with" legislative clearance by OMB, they might also be categorized as presidential bills. But we argue that these independent agencies may be sending proposals to OMB for clearance simply because they find the feedback useful in improving their legislative proposals, rather than to secure presidential approval. 